\title{
Advective Heat Transport and the Salt Chimney Effect: A Numerical Analysis
}

\author{
David P. Canova, ${ }^{1}$ Mark P. Fischer, ${ }^{1}$ Richard S. Jayne, ${ }^{2}$ and Ryan M. Pollyea $\mathbb{D}^{2}$ \\ ${ }^{1}$ Department of Geology and Environmental Geosciences, Northern Illinois University, DeKalb, IL 60115, USA \\ ${ }^{2}$ Department of Geosciences, Virginia Polytechnic Institute \& State University, Blacksburg, VA 24061, USA \\ Correspondence should be addressed to Ryan M. Pollyea; rpollyea@vt.edu
}

Received 2 March 2018; Revised 23 April 2018; Accepted 2 May 2018; Published 9 July 2018

Academic Editor: Timothy S. Collett

Copyright (C) 2018 David P. Canova et al. This is an open access article distributed under the Creative Commons Attribution License, which permits unrestricted use, distribution, and reproduction in any medium, provided the original work is properly cited.

\begin{abstract}
We conducted numerical simulations of coupled fluid and heat transport in an offshore, buried salt diapir environment to determine the effects of advective heat transport and its relation to the so-called "salt chimney effect." Model sets were designed to investigate (1) salt geometry, (2) depth-dependent permeability, (3) geologic heterogeneity, and (4) the relative influence of each of these factors. Results show that decreasing the dip of the diapir induces advective heat transfer up the side of the diapir, elevating temperatures in the basin. Depth-dependent permeability causes upwelling of warm waters in the basin, which we show to be more sensitive to basal heat flux than brine concentration. In these model scenarios, heat is advected up the side of the diapir in a narrower zone of upward-flowing warm water, while cool waters away from the diapir flank circulate deeper into the basin. The resulting fluid circulation pattern causes increased discharge at the diapir margin and fluid flow downward, above the crest of the diapir. Geologic heterogeneity decreases the overall effects of advective heat transfer. The presence of low permeability sealing horizons reduces the vertical extent of convection cells, and fluid flow is dominantly up the diapir flank. The combined effects of depth-dependent permeability coupled with geologic heterogeneity simulate several geologic phenomena that are reported in the literature. In this model scenario, conductive heat transfer dominates in the basal units, whereas advection of heat begins to affect the middle layers of the model and dominates the upper units. Convection cells split by sealing layers develop within the upper units. From our highly simplified models, we can predict that advective heat transport (i.e., thermal convection) likely dominates in the early phases of diapirism when sediments have not undergone significant compaction and retain high porosity and permeability. As the salt structures mature into more complex geometries, advection will diminish due to the increase in dip of the salt-sediment interface and the increased hydraulic heterogeneity due to complex stratigraphic architecture.
\end{abstract}

\section{Introduction}

Salt structures cause anomalous temperature distributions throughout many sedimentary basins due to the high thermal conductivity of salt as compared to other sedimentary rocks $[1-8]$. The strong thermal conductivity contrasts between salt rocks and the surrounding sediments result in higher heat fluxes through salt diapirs and thus increased temperatures above salt domes, creating what has become known as the "salt chimney effect" (Figure 1; $[2,6,8-14]$ ). This effect has the potential to dramatically alter the generation, movement, accumulation, and preservation of hydrocarbons and other fluids in the vicinity of salt structures.
These fluid-related processes can in turn alter the temperature distribution in the rocks surrounding a salt structure, creating a complex feedback system amongst the evolving salt structure, the temperatures in the enveloping rocks, and the nearby fluid system.

Analyses of salt thermal effects and their role in saltrelated fluid systems have progressed from early models of conductive heat transfer through salt rocks to models that incorporate thermal convection, salt dissolution, and advective fluid flow. Salt diapirs in early studies were modeled as perfectly cylindrical structures in a homogenous and isotropic sedimentary medium (e.g., $[9,15])$. These and other studies clearly identify positive temperature anomalies above 


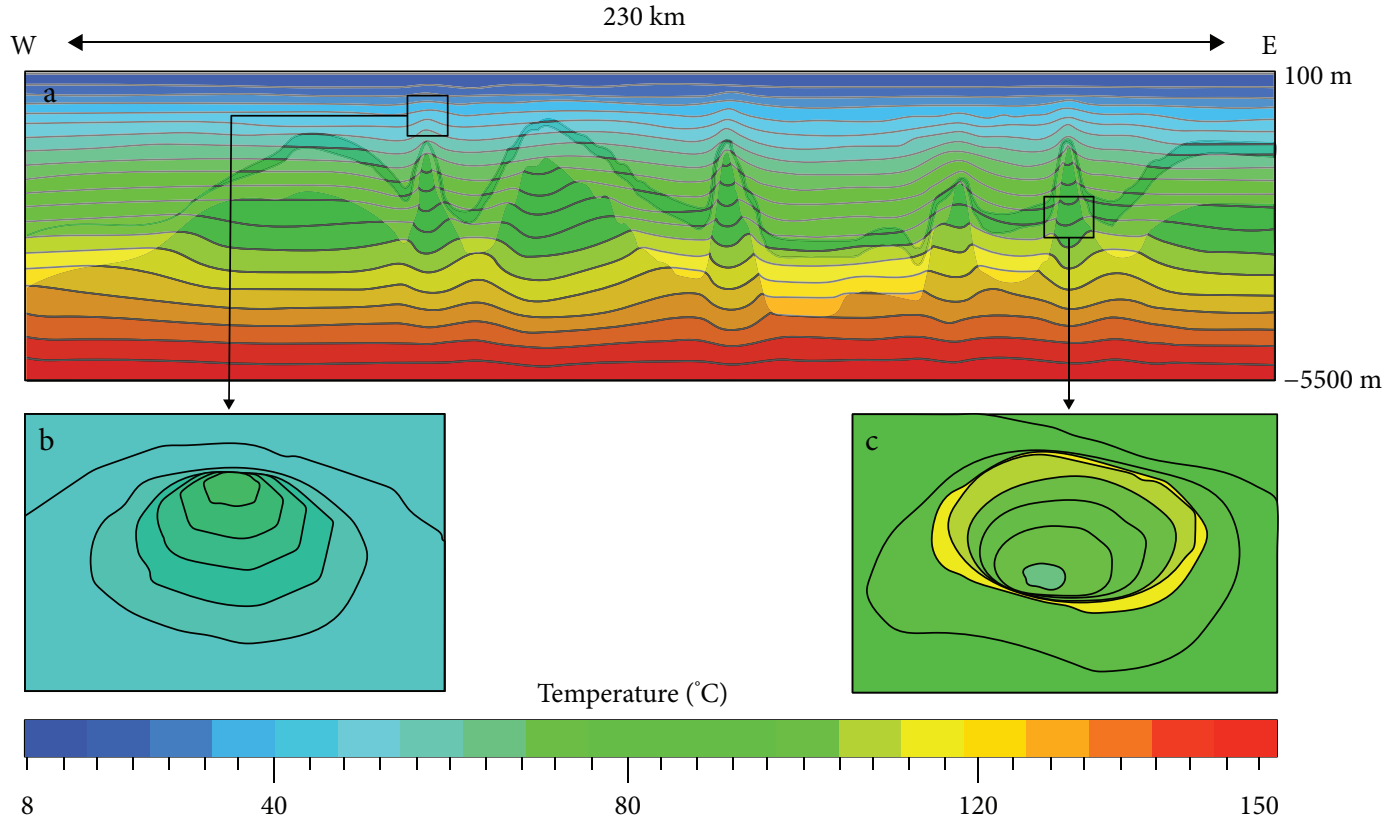

FIGURE 1: The salt chimney effect. (a) A cross section through the North East German Basin showing salt structures as the dark shaded region in the bottom and temperature isotherms as the gray lines. (b) A close up 3-D representation of box 1 in panel (a) of convex isotherms above buried salt diapirs. (c) A 3-D representation of box 2 in panel (a) of concave isotherms within and below buried salt diapirs; modified from Kaiser et al. [6].

salt domes and negative temperature anomalies below buried salt diapirs $[2,5-8,11,16-18]$, with the largest anomalies at the top and bottom of the dome (Figure 1). Sarkar et al. [18] modeled the fluid system beneath allochthonous salt sheets in the Gulf of Mexico region and concluded that temperature and dissolution-related salinity differences could be significant variables driving convective fluid flow. Recent, basin-scale studies in the Northeast German Basin concluded that advective heat transport could play a significant role in heat transfer on the minibasin scale $(\sim 1-10 \mathrm{~km})$, potentially reorganizing the thermal structure of minibasins adjacent to diapirs $[2,6]$. Although these studies lacked the resolution to definitively characterize this behavior, they suggested that advection could reduce the thermal anomaly associated with salt structures by transporting heat away from a structure or that it could enhance the thermal anomaly by advecting heat up the diapir flank.

1.1. Motivation. Salt structures and their related minibasins are associated with complex and evolving fluid systems that reflect their structural and stratigraphic evolution. A shortcoming of many numerical modeling studies is that they fail to integrate the dynamic evolution of diapirs and their related minibasins through time. They assume a present geometry and assess the fluid system at a single point in time, whereas in reality, these fluid systems evolve along with the salt structure, inheriting characteristics from each stage of sedimentation and diapirism. To evaluate the fluid system and thermal structure development through time, we must understand how the fundamental evolution of salt structures is going to affect the fluid system and temperature distribution in the minibasins. Moreover, if we wish to understand the relative significance of salt dissolution and thermal structure on salt-related fluid systems, we need models that independently assess how the fluid circulation system responds to independent changes in these variables.

The local-scale, thermally driven fluid system near salt structures has the potential to impact hydrocarbon maturation, degradation, and migration, as well as petroleum systems and prospect risking $[2,5,6,8,19]$. Advective heat transfer has the potential to expand or shrink the hydrocarbon window adjacent to salt structures and could also lead to hydrocarbon destruction via bacterial and thermochemical sulfate reduction (e.g., sour gas creation; $[2,6,8]$ ). By modifying the temperature distribution in the vicinity of a diapir, advection could affect methane hydrate stability, fluid pressure distribution, Earth stress, diagenetic reactions, microbial processes, the distribution and migration of hydrocarbons, and the creation and occlusion of reservoir porosity $[11,15]$. Understanding how advective heat transfer affects the temperature distribution near salt bodies is a first step toward refining and improving our models of salt-related petroleum systems and more accurately assessing the risk that is inherent in these complex plays.

This paper employs fully coupled numerical simulations of fluid and heat flow to investigate advective heat transport and the onset of thermal convection adjacent to a salt diapir. In order to independently assess the impact of a near-salt thermal structure on fluid advection and thermal convection, our modeling approach initially omits the effects of salt dissolution by focusing primarily on the interactions between thermal fluid circulation and geologic heterogeneity. After 


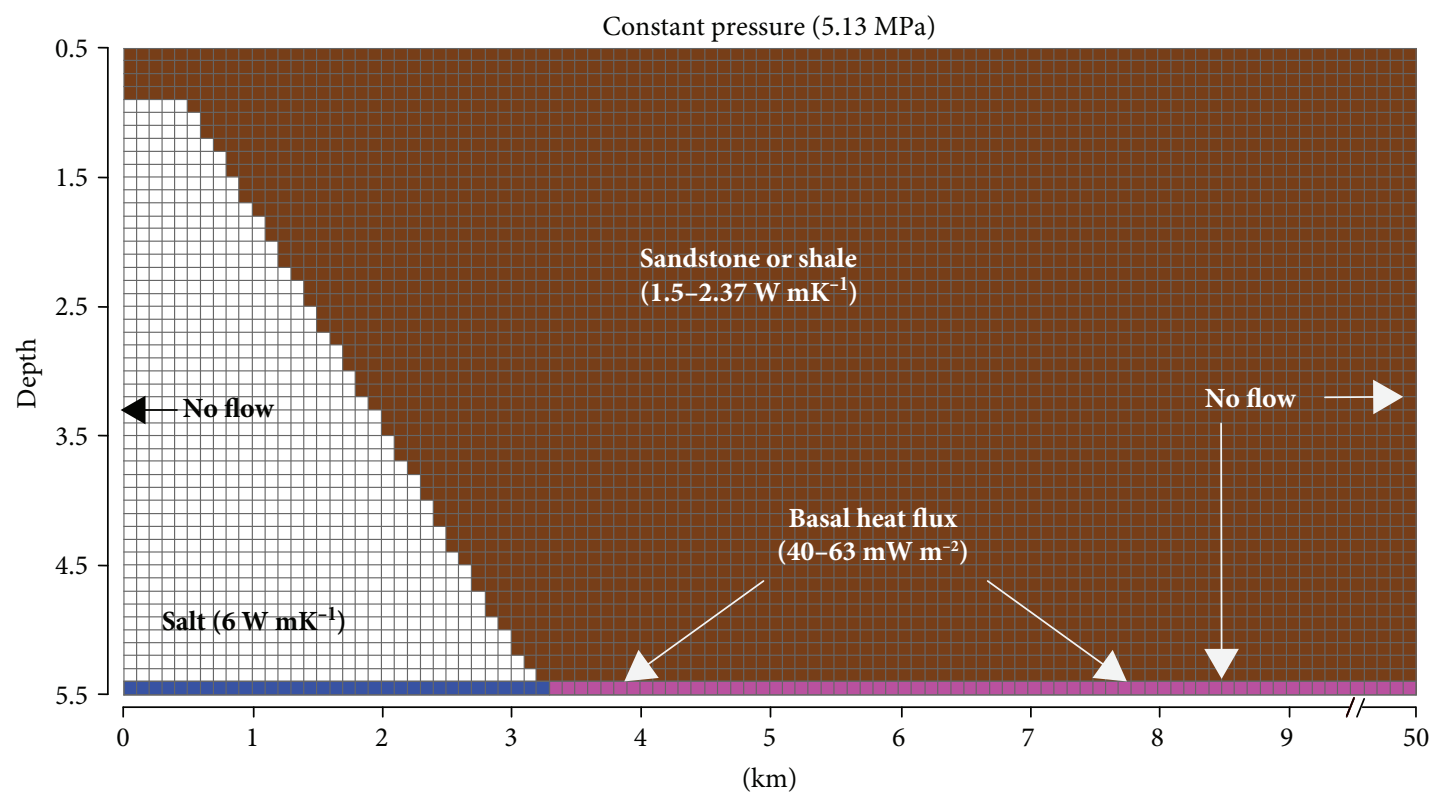

FIGURE 2: Initial model configuration. A schematic diagram of the initial model setup. No flow boundaries are imposed across the bottom and sides of the model, and the top of the model is set at a constant hydraulic head $500 \mathrm{~m}$ below sea level. The white area represents salt rocks; the brown area represents sandstone or shale depending on the modeling run. The bottom cells (pink and blue) are all assigned a constant heat flux through sediments with the same thermal and physical properties of the overlying units.

TABLE 1: Rock properties.

\begin{tabular}{lcccc}
\hline Lithology & $\begin{array}{c}\text { Permeability } k \\
\left(10^{-15} \mathrm{~m}^{2}\right)\end{array}$ & Porosity $\Phi$ & $\begin{array}{c}\text { Thermal conductivity } \lambda \\
\left(\mathrm{W} \mathrm{m}^{-1} \mathrm{~K}^{-1}\right)\end{array}$ & $\begin{array}{c}\text { Grain specific heat } \mathrm{C}_{\mathrm{p}} \\
\left(\mathrm{J} \mathrm{kg}^{-1} \mathrm{~K}^{-1}\right)\end{array}$ \\
\hline Sandstone & 2.5 & 0.13 & 2.37 & $\begin{array}{c}\text { Density } \rho_{\mathrm{r}} \\
\left(\mathrm{kg} \mathrm{m}^{-3}\right)\end{array}$ \\
Shale & 0.01 & 0.08 & 1.5 & $9.20 \times 10^{-4}$ \\
Salt & 0.0001 & 0.01 & 6 & $9.20 \times 10^{-4}$ \\
\hline
\end{tabular}

developing a comprehensive understanding of thermal fluid circulation and geologic heterogeneity, we implement a limited set of reactive transport models to assess the effects of fully coupled thermohaline fluid circulation within a diapir margin. Because our purpose is to probe the complex feedback relationships between salt-related fluid system behavior and the salt chimney effect, we neglect deformation-induced changes in porosity, permeability, and fluid pressure, which are beyond the scope of our work. In addition, the scale of our investigation is limited to an area adjacent to a salt diapir and up to $10 \mathrm{~km}$ into the adjacent minibasin.

\section{Numerical Modeling Methods}

The initial model domain comprises a two-dimensional (2-D) cross section of a radially symmetric diapir located $500 \mathrm{~m}$ below sea level and $400 \mathrm{~m}$ below the sea floor (Figure 2). The top boundary of the model is specified as a Dirichlet condition at $5^{\circ} \mathrm{C}$ and $5.13 \mathrm{MPa}$ of fluid pressure to represent seafloor conditions. Salt is assigned a porosity of $1 \%$ and permeability of $10^{-19} \mathrm{~m}^{2}$. The sedimentary, diapiradjacent rocks are initially modeled as homogenous and isotropic (Table 1; [20]), but in later models, stratigraphic heterogeneity is considered, including the occurrence of low permeability sealing intervals and systematically decreasing permeability with depth. In all numerical simulations, the hydraulic and thermal properties are static and do not vary as a function of temperature, pressure, or time. We note here that Lerche [21] found that the temperature dependence of thermal conductivity is negligible in both sandstone and shale for typical bedding thickness; however, the thermal conductivity of salt decreases by $\sim 1 / 3$ from 0 to $127^{\circ} \mathrm{C}$ and the associated heat flux may vary up to $\sim 13 \%$. In order to account for this variability, the models presented here implement two different heat flow regimes characterized by basal heat flux of 40 and $63 \mathrm{~mW} \mathrm{~m}^{-2}$, which result in temperature gradients of 25 and $35^{\circ} \mathrm{C} \mathrm{km}^{-1}$, respectively. In addition, this study generally assumes no salt dissolution throughout the model domain and that all fluid flow is driven by thermal gradients associated with the salt structure (i.e., no salt top topography or salinity gradients); however, we test the implications of this assumption with a smaller suite of reactive transport models that account for both salt dissolution and transport. For all model scenarios, each domain is discretized as a regular, 2-D Cartesian grid with 25,000 cells $(X=500$ cells, $Z=50$ cells), in which each cell is $100 \mathrm{~m} \times 100 \mathrm{~m}$. The 


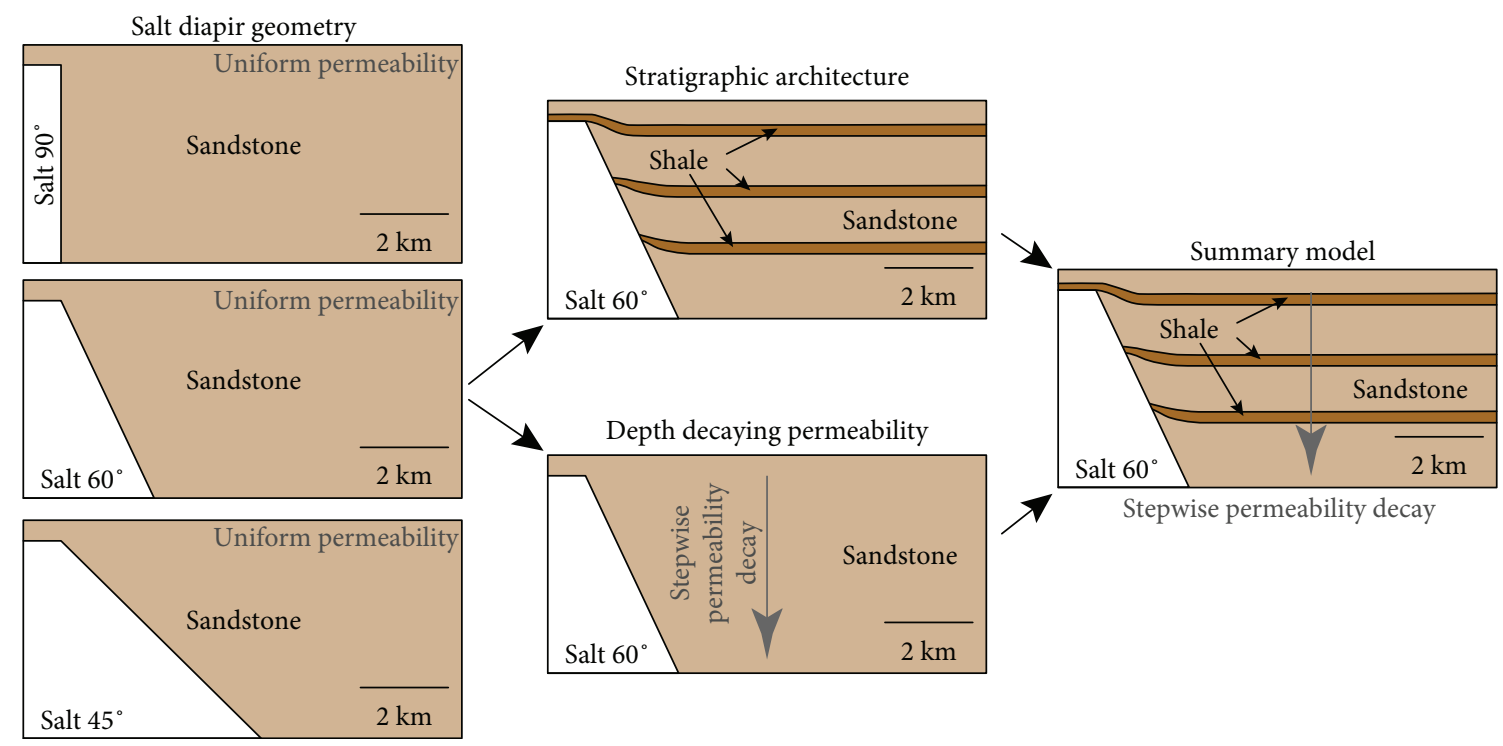

Figure 3: Schematic model domains. The schematic diagrams show the conceptual model created for each scenario. White represents salt rocks, light brown represents sandstones, and dark brown represents shales. Models were run with increasing geologic heterogeneity adding one complexity at a time.

model mesh also includes an arbitrary out-of-plane thickness of $1 \mathrm{~m}$ because the solution scheme is an integral finite difference solver for space discretization.

Before simulations, initial conditions were computed to establish the baseline temperature and pressure distribution for each model domain. The initial conditions represent fully saturated, hydrostatic conditions ranging from $500 \mathrm{~m}$ below sea level $\left(P_{\mathrm{f}}=5.13 \mathrm{MPa}\right)$ to $5500 \mathrm{~m}$ below sea level $\left(P_{\mathrm{f}}=50.36 \mathrm{MPa}\right)$. Dirichlet boundaries are imposed at the surface to maintain the hydrostatic pressure gradient. The far-field boundary (right side of model domain) is adiabatic (i.e., no flow) to fluid pressure and heat flow, and this boundary is $50 \mathrm{~km}$ away to mitigate the potential for feedbacks from the boundary condition to affect the near-field $(<10 \mathrm{~km})$ solution. In keeping with other diapirrelated flow models, we assume a radially symmetric diapir and adiabatic boundaries are imposed across the bottom and left edge of each model domain. A constant heat flux ( 40 or $63 \mathrm{~mW} \mathrm{~m}^{-2}$ ) is imposed across the bottom boundary to induce a geothermal gradient ranging from 25 to $35^{\circ} \mathrm{Ckm}^{-1}$, depending upon the simulation. Thermal conductivity, permeability, porosity, rock grain specific heat, and density are averaged for salt, sandstone, and shale lithologies from the Gulf of Mexico (GOM) for all models and are shown in Table $1[18,22]$. We note here that initial conditions reflect primarily hydrostatic conditions, and local overpressuring is not accounted for in the initial state.

Groundwater flow is simulated in each model domain for 500,000 years, providing sufficient time to achieve steady flow within each scenario. The code selection for this work is TOUGH2, compiled with EOS1, the equation of state module for simulating nonisothermal, multiphase conditions [23]. TOUGH2/EOS1 solves the coupled equations for heat transfer and fluid flow in an integral finite volume numerical scheme. In this formulation, the temperature-dependent properties of water (e.g., density, viscosity, and specific enthalpy) are updated for each grid cell at each iteration using the steam table equations [24]. In order to evaluate the effects of salt dissolution, a limited set of reactive transport models is performed using a prerelease version of TOUGH3 [25] compiled with ECO2Nv2 [26], which is the equation of state module for simulating nonisothermal mixtures of water, $\mathrm{CO}_{2}$, and $\mathrm{NaCl}$ in porous geologic media at temperatures up to $300^{\circ} \mathrm{C}$. In this formulation, phase partitioning between solid- and aqueous-phase $\mathrm{NaCl}$ assumes local equilibrium but accounts for thermal effects of $\mathrm{NaCl}$ solubility in water. These simulations comprise identical model specifications as described above and are designed to test the relative contributions of thermal and haline effects.

The model results presented here assess the combined effects of conductive and advective heat transport caused by groundwater flow. As shown in Figure 3, these models systematically evaluate coupled changes in a fluid and thermal system structure in response to (1) salt diapir geometry, (2) depth-decaying permeability, (3) stratigraphic heterogeneity/architecture similar to that in composite halokinetic sequences, and (4) combined depth-dependent permeability and stratigraphic heterogeneity. The first set of models investigates how the dip of the salt-sediment interface affects convective flow and advective heat transfer. The second set of models investigates how vertical permeability gradients affect the heat distribution and whether permeability decay stimulates or impedes convective flow and advective heat transfer. The depth-decaying permeability scenario is also used as the test case to understand how salinity gradients interact with thermal fluid circulation on the diapir margin. The third set of models incorporates heterogeneous growth strata to evaluate the impact of minibasin sealing layers, while providing insights into the potential for up-dip, stratal terminations to trap hydrocarbons. The last set of models combines geologic 
TABle 2: Nomenclature.

\begin{tabular}{|c|c|c|c|}
\hline Symbol & Description & SI unit & Values \\
\hline $\bar{k}$ & Permeability & $\mathrm{m}^{2}$ & $2.50 \times 10^{-15}$ \\
\hline$z$ & Thickness of reservoir & $\mathrm{m}$ & 5000 \\
\hline$\beta$ & Water expansivity & ${ }^{\circ} \mathrm{C}^{-1}$ & $6.10 \times 10^{-4}$ \\
\hline$\nabla T$ & Temperature change over domain & ${ }^{\circ} \mathrm{C}$ & 125 \\
\hline$g$ & Gravity & $\mathrm{m}^{2} \mathrm{~s}^{-1}$ & 9.8 \\
\hline$k_{\theta}$ & Thermal diffusivity of saturated matrix & $\mathrm{m}^{2} \mathrm{~s}^{-1}$ & $1.43 \times 10^{-7}$ \\
\hline $\bar{V}$ & Water viscosity & $\mathrm{m}^{2} \mathrm{~s}^{-1}$ & $6.30 \times 10^{-7}$ \\
\hline$\Gamma$ & Ratio of volume heat capacity of saturated matrix to fluid & Dimensionless & 0.80 \\
\hline$\gamma$ & Coefficient of fluid density dependence on salinity & wt $(\%)^{-1}$ & 0.01 \\
\hline$R_{a}$ & Rayleigh number & Dimensionless & \\
\hline$P_{e}$ & Péclet number & Dimensionless & \\
\hline
\end{tabular}

heterogeneity and stratigraphic architecture to assess the relative role of each of these components in a more realistic scenario (Figure 3).

2.1. Critical Permeability Threshold. The classical RayleighTaylor instability theory can be used to demarcate convective flow in homogenous systems, although its applicability to heterogeneous systems is limited [27-29]. To investigate the onset of advection near salt diapirs, we first calculate a critical permeability threshold for a simple system using the Rayleigh and Péclet numbers and the values given in Table 2. The Rayleigh number is a dimensionless parameter that describes fluid system instability caused by density gradients. Sarkar et al. [18] and Huysmans and Dassargues [30] formulate the Rayleigh number $\left(R_{a}\right)$ in the context of porous geologic media as

$$
R_{a}=\frac{k z \beta \nabla T g}{\bar{V} k_{\theta}}
$$

where the variable definitions and units are provided in Table 2. A Rayleigh number $\geq 40$ represents an unstable system where convective heat transfer will dominate the thermal behavior of the system. The onset of advection is often described using the Péclet number $\left(P_{e}\right)$, which is a dimensionless quantity that describes the ratio of advective heat transfer to diffusive heat transfer $[18,30]$. Using the parameters presented in Table 2, the Péclet number for our model domain is calculated as

$$
P_{e}=\frac{\text { Advective transfer rate }}{\text { Dif fusive transfer rate }}=0.056\left(\frac{k g z}{\bar{V} \Gamma k_{\theta}}\right) \gamma,
$$

when $P_{e}$ is greater than or equal to one, groundwater flow will begin to alter the subsurface temperature field.

The Péclet number for our models is very sensitive to the reservoir permeability, with changes of $\pm 0.2 \times 10^{-15} \mathrm{~m}^{2}$ causing a drastic reorganization of the thermal structure adjacent to the diapir (Figure 4). For the initial model domain, the critical permeability of $2.5 \times 10^{-15} \mathrm{~m}^{2}$ results in $P_{e} \approx 0.9$ (Figure 4 ). We identified this critical permeability by adjusting the permeability within the model domain until vertical heat flow vectors begin to deflect towards the salt structure, indicating that fluid circulation adjacent to the diapir is causing significant advective heat transfer in the minibasin. At this critical permeability threshold, advective heat transport dominates the thermal structure and fluid flow vectors and heat flow vectors mirror each other [18, 30, 31]. The critical permeability threshold we identified was used to test the relative influence of salt geometry and stratigraphic architecture/geologic heterogeneity on the onset of advection in the near salt environment.

\section{Results}

3.1. Salt Diapir Geometry. We varied the homoclinal dip of the salt-sediment interface from $90^{\circ}$ to $45^{\circ}$ to investigate the first-order influence of diapir geometry on advective heat transfer near salt diapirs (Figure 5). Each of the three scenarios was run at the critical permeability of $2.5 \times 10^{-15} \mathrm{~m}^{2}$. Groundwater flow and heat transport for a vertical (90 dip) salt-sediment interface show a conduction-dominated system with heat flow vectors just beginning to deflect towards the salt structure. Fluid circulation occurs in the sediments adjacent to the diapir, but there is no significant effect on the temperature distribution within the basin; thus, heat transport is controlled by conduction through the diapir and adjacent sediments. Similarly, conductive heat transfer through the vertical salt diapir controls the thermal anomaly associated with the salt chimney effect.

Heat transport in the model with a $60^{\circ}$ dipping saltsediment interface is almost fully advection dominated, with fluid flow vectors and heat flow vectors closely mirroring each other. Compared to the case with a vertical saltsediment interface, fluid velocities along the diapir flank increase, resulting in the advection of warm waters up the diapir flank. The increased fluid flux up the diapir flank is balanced by the infiltration of cold seawater into the central parts of the minibasin. Advective heat transport elevates temperatures adjacent to the diapir and diminishes temperatures further into the minibasin. When the dip of the diapir flank is decreased, the thermal anomaly associated with the salt chimney effect is dominated by the advection of warm waters up the diapir flank, which eventually discharge at the diapir margin. 


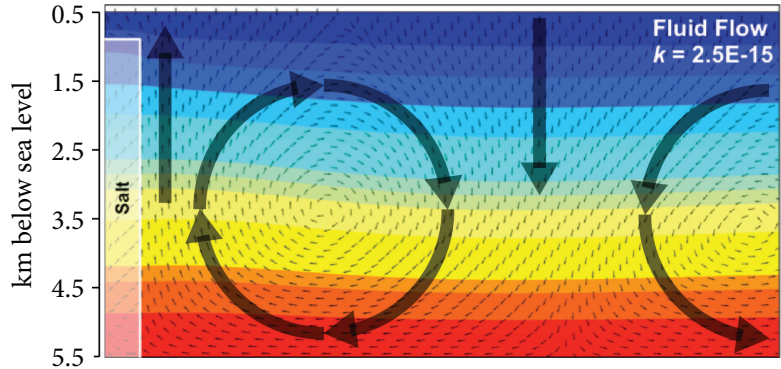

(a)

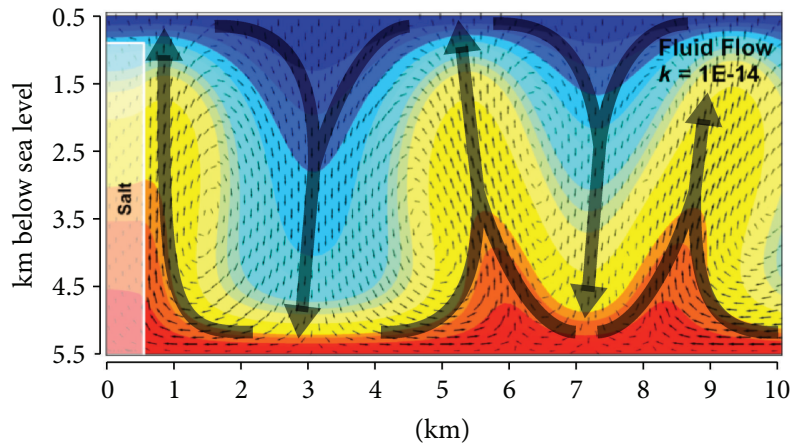

(c)

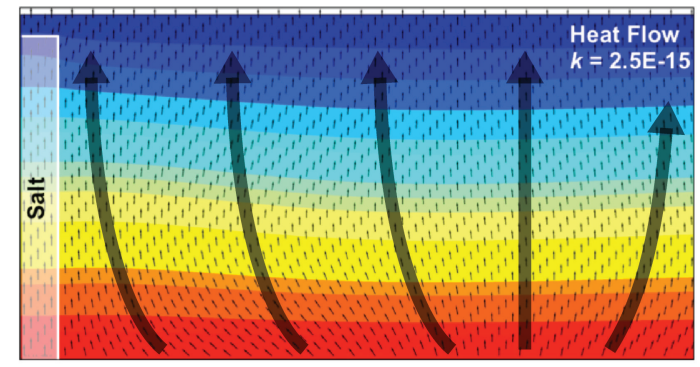

(b)

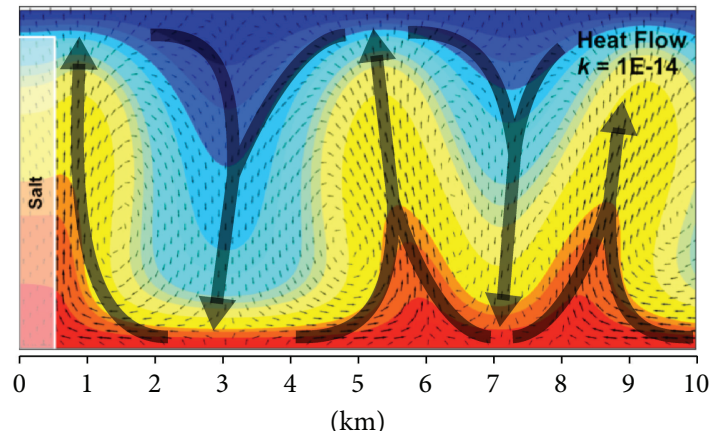

(d)

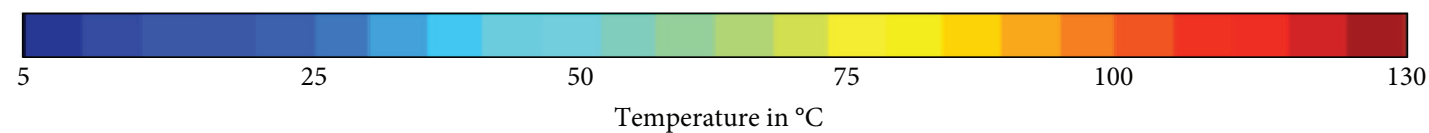

Figure 4: Panels (a) and (b) show fluid flow (a) and heat flow (b) vectors at the critical permeability $\left(2.5 \times 10^{-15} \mathrm{~m}^{2}\right)$. The heat flow vectors begin to mirror the direction of fluid movement indicating a transition to advective heat transfer. Panels (c) and (d) show an identical model run when permeability is less than one order of magnitude higher; the fluid vectors and heat vectors mirror each other indicating advective heat transport is the dominant processes. Although we ran simulations out to $50 \mathrm{~km}$, we only present the first $10 \mathrm{~km}$ of the model domain and focus our analysis here. Dark gray arrows denote general flow directions, while small black arrows are simulated mass (a, c) or heat (b, d) flux vectors (scaled by magnitude).

For the case with a $45^{\circ}$ dipping salt-sediment interface, fluid flow and heat transport are tightly coupled, resulting in vigorous advective heat transport that elevates temperatures along the diapir flank. Fluid velocities increase and heat is drawn further up the diapir flank, while cold waters are drawn deeper into the minibasin. Heat transport in the minibasin is fully advective, the thermal structure is strongly influenced by the dip of the salt-sediment interface, and the salt chimney effect is largely associated with advected warm waters along the flank of the diapir, rather than conduction through the diapir itself.

In summary, the results of this model set indicate that decreasing the dip of a diapir flank causes increased fluid velocities, which in turn cause the main heat transport process to shift from a conduction-dominated system to an advection-dominated system. The dip of the diapir flank has a dramatic influence on the thermally driven fluid system structure. As dip decreases, fluid flux up the diapir flank increases, causing greater seawater infiltration into the minibasin. As fluid flux in the minibasin increases, the cause of the salt chimney effect is shifted from conduction through the diapir to the advection of warm waters up the diapir flank, increasing temperatures adjacent to the salt structure.
3.2. Stratigraphic Architecture. The stratigraphic architecture in minibasins and adjacent to salt bodies can be complex and highly heterogeneous (e.g., [4, 6, 32]). As noted by Giles and Rowan [33], stratal terminations against salt may be abrupt or gradual, and associated folding may be focused in a $<200 \mathrm{~m}$ wide zone adjacent to salt (e.g., hook halokinetic sequence) or extend up to $1 \mathrm{~km}$ away from the salt-sediment interface (e.g., wedge halokinetic sequence). Moreover, minibasin sediments are never strictly isotropic and homogeneous; sealing units are present at different stratigraphic levels, and porosity and permeability are known to decrease with depth [22, 34-36]. All of these added complexities should influence the movement of fluid near salt diapirs and, therefore, the salt chimney effect.

We conducted a series of models to investigate how changing the depth and geometry of a laterally continuous $200 \mathrm{~m}$ thick sealing layer may affect heat transfer and fluid flow near a salt diapir with a $60^{\circ}$ homoclinal dipping saltsediment interface (Figure 6). As shown in Figures 6 and 7, minibasin sealing layers segment and compartmentalize the fluid system. Sealing layers tend to "cap" convective cells and effectively decouple the thermal structure of the minibasin, creating two discrete fluid systems. This causes different heat transport mechanisms to dominate permeable horizons 


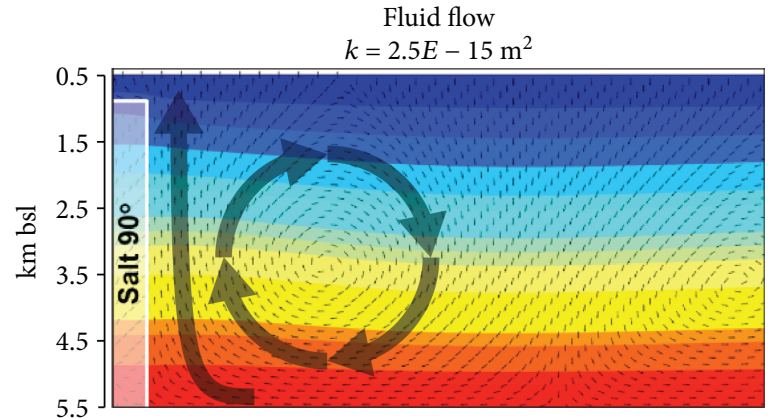

(a)

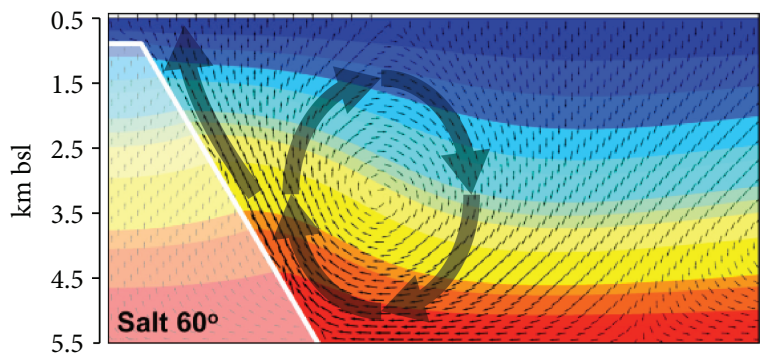

(c)

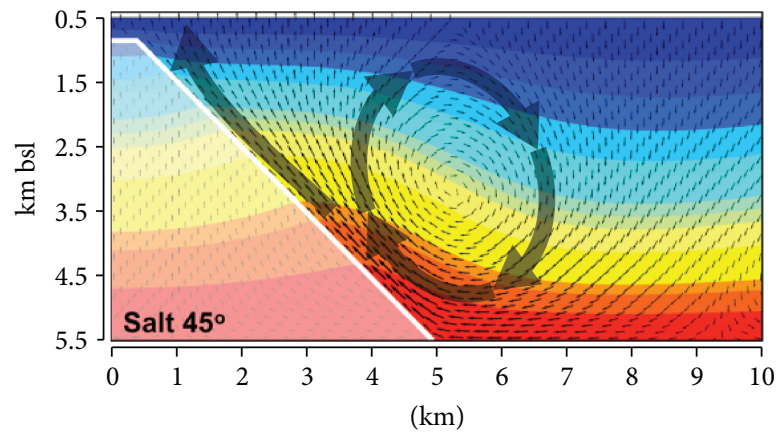

(e)

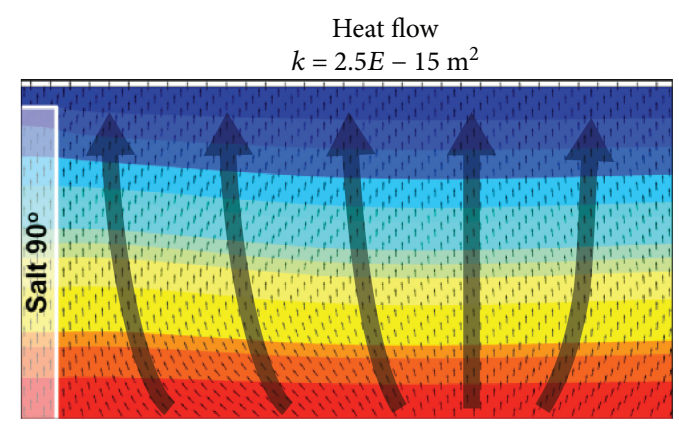

(b)

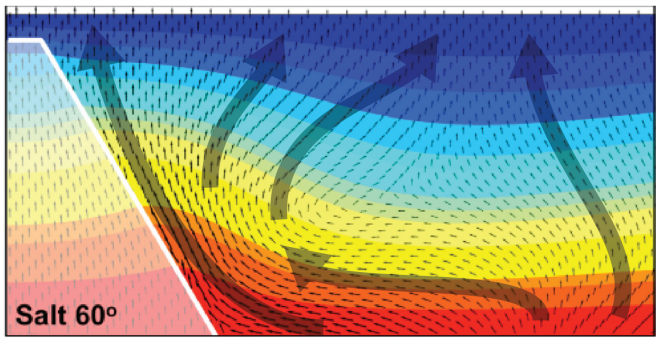

(d)

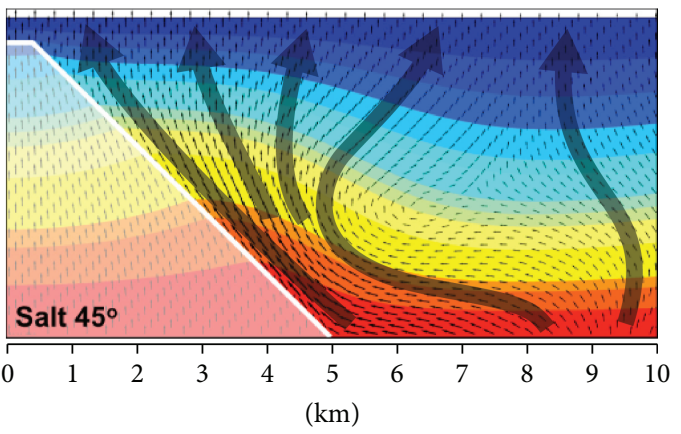

(f)

Fluid flow vectors $\left(\mathrm{kg} \mathrm{s}^{-1} \mathrm{~m}^{-2}\right)$ Max: $8.2 E-7$

Min: $8.3 E-17$

Heat flow vectors $\left(\mathrm{W} \mathrm{m}^{-2}\right)$ Max: 0.46

Min: $5.92 E-4$

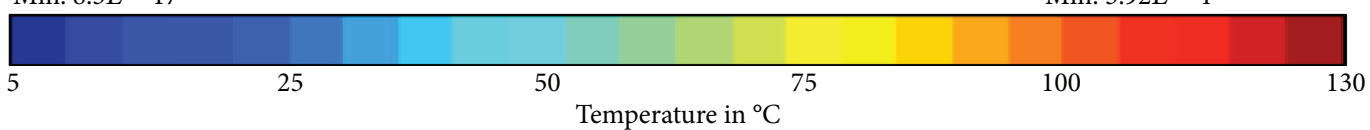

FiguRE 5: Model results for an axially symmetric diapir with a salt-sediment interface dipping at $90^{\circ}(\mathrm{a}, \mathrm{b}), 60^{\circ}$ (c, d), and $45^{\circ}$ (e, f). The colors represent temperature, the shaded white region represents salt, and the vectors represent either mass flux $\left(\mathrm{kg} \mathrm{s}^{-1} \mathrm{~m}^{-2}\right)(\mathrm{a}, \mathrm{c}, \mathrm{e})$ or heat flow $\left(\mathrm{W} \mathrm{m}^{-2}\right)(\mathrm{b}, \mathrm{d}, \mathrm{f})$. Dark gray arrows denote general flow directions.

depending upon the thickness, continuity, and structural position of the reservoir. Thick and permeable stratigraphic horizons favor advective heat transport while thin reservoirs are characterized by conduction. When three sealing layers are added to the model domain, creating highly heterogeneous stratigraphy, advective heat transfer is greatly diminished and only affects sediments near the salt, and the large-scale thermal structure is controlled by conduction. Overall, the effects of advective heat transfer are reduced, and conduction through the salt diapir dominates the thermal anomaly associated with the salt chimney effect.

The permeability structure within the top $1 \mathrm{~km}$ of the model domain controls whether the salt chimney effect is dominated by advection of warm waters along the diapir flank or by conduction through the salt. If the stratigraphy in this upper kilometer is homogenous and permeable, advection will drive the thermal anomaly above the salt structure.

Given a large enough permeability contrast between units, hook- and wedge-style terminations cause fluid to circulate within discrete hydrologic zones. Regardless of the style of termination (i.e., wedge or hook), fluids are trapped below the upturned portions of the sealing unit, and the volume of trapped fluid is dependent upon the amount of upturn related to halokinetic folding. Fluid velocities are greatest above and below the fold hinge of wedge sequences, driving warm waters towards the diapir in the bottom of the 


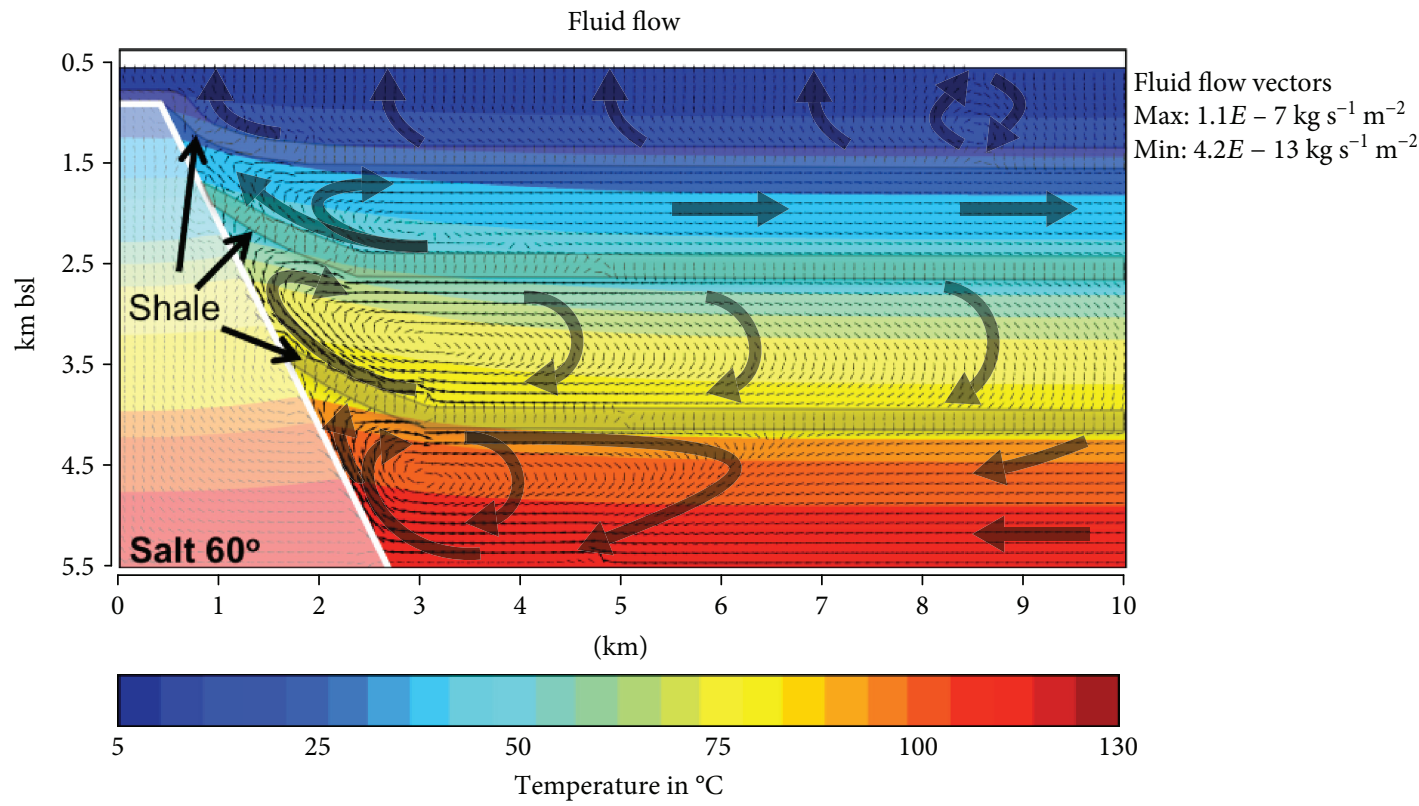

(a)

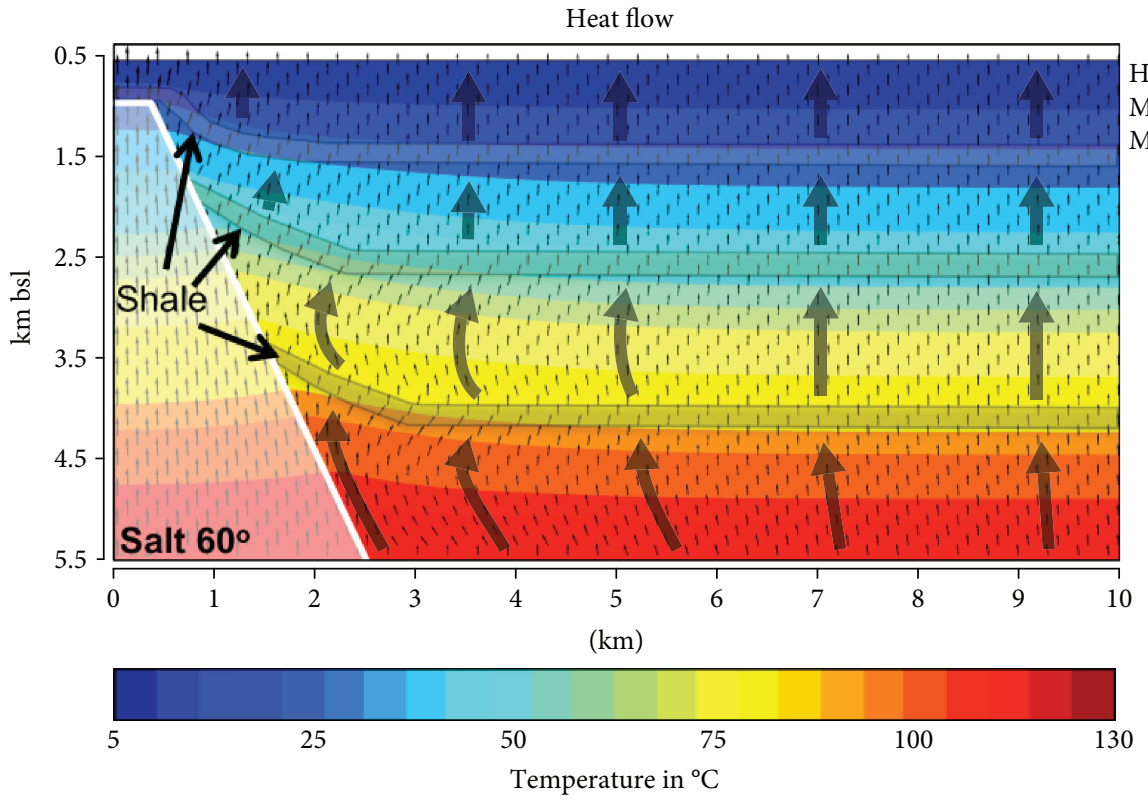

Heat flow vectors Max: $0.175 \mathrm{~W} \mathrm{~m}^{-2}$ Min: $0.037 \mathrm{~W} \mathrm{~m}^{-2}$

(b)

Figure 6: Fluid (a) and heat (b) flow patterns in a model with three sealing layers. The shale units (dark shaded horizons) are modeled with a permeability of $1 \times 10^{-17} \mathrm{~m}^{2}$, and the remaining sediments retain the critical permeability of $2.5 \times 10^{-15} \mathrm{~m}^{2}$. Dark gray arrows denote general flow directions, while small black arrows are simulated mass (a) or heat (b) flux vectors (scaled by magnitude).

permeable interval and advecting heat away from the diapir in the top of that interval.

3.3. Depth-Decaying Permeability. In many sedimentary basins, it is well established that increasing compaction with depth causes a corresponding decrease in permeability $[22,34,35]$. To constrain the impact of this behavior on the fluid system and temperature distribution near salt diapirs, we imposed a depth-dependent permeability trend in the minibasin adjacent to a $60^{\circ}$ dipping, salt diapir. The depth-dependent permeability decay $(k(z))$ model employed for this study is given by

$$
k(z)=\zeta(\mathrm{z}) k_{s}
$$

where $\zeta(z)$ is a scaling coefficient and $k_{s}$ is the permeability at the sea floor. The formulation for $\zeta(\mathrm{z})$ invokes the permeability scaling model proposed by Saar and Manga [36], which is a piecewise function based in part on the power-law scaling model originally proposed by Manning and Ingebritsen 


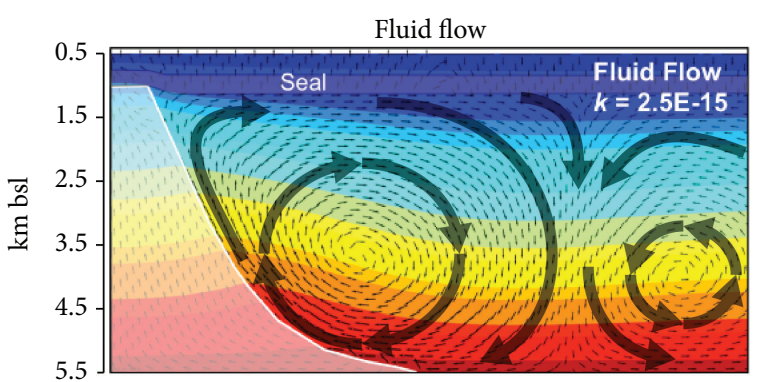

(a)

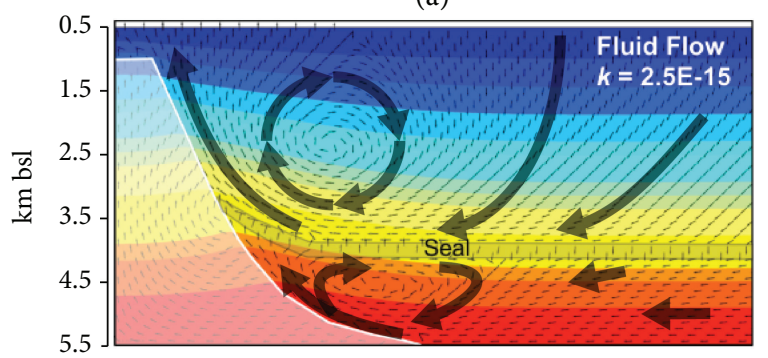

(c)

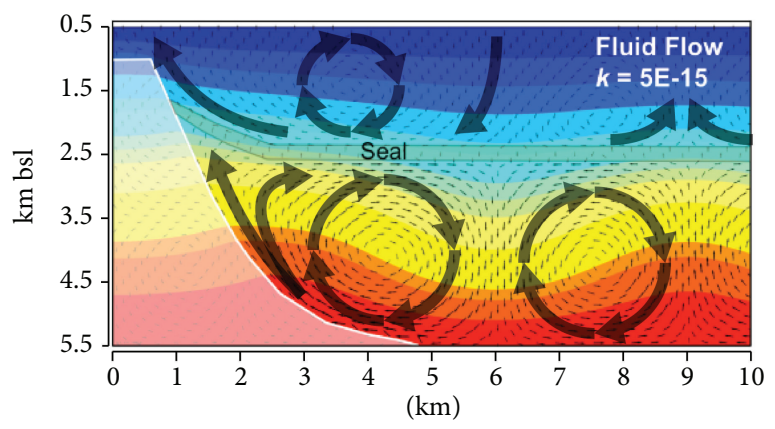

(e)

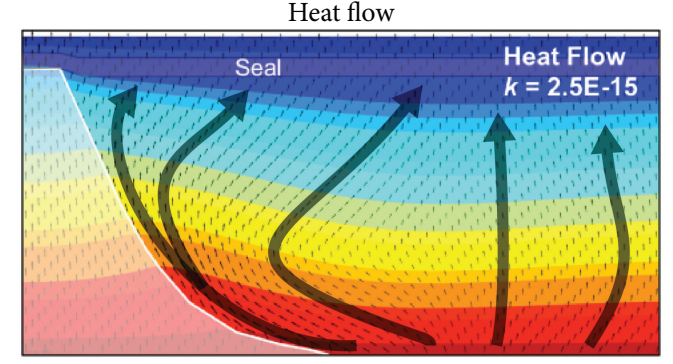

(b)

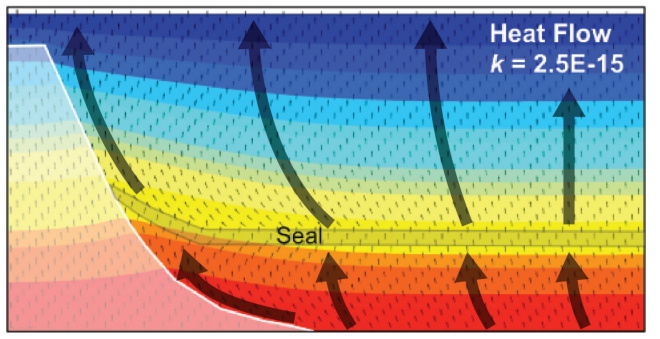

(d)

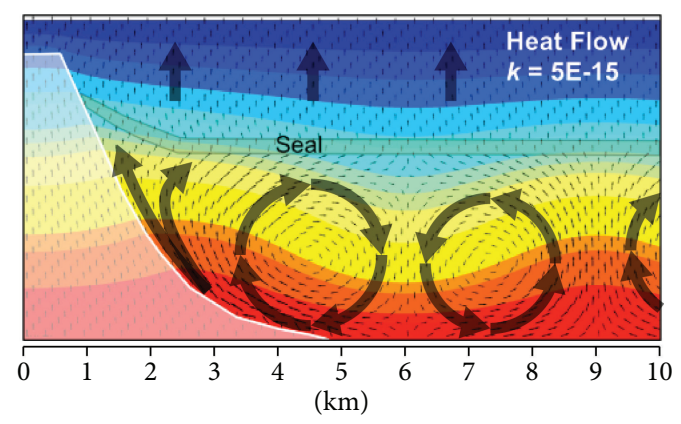

(f)

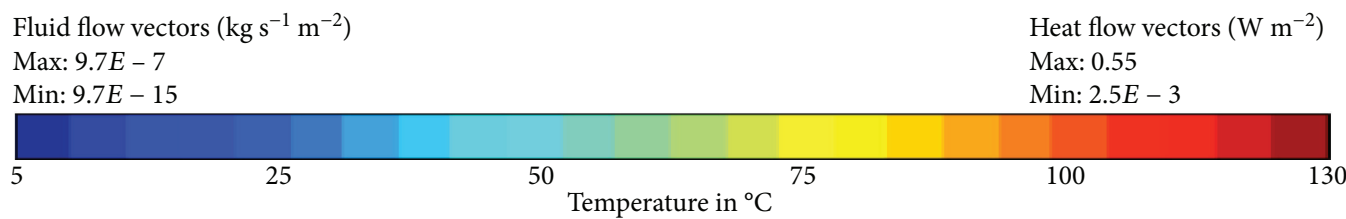

Figure 7: Fluid ( $a, c, e)$ and heat flow (b, d, f) patterns from models with shale sealing layers at variable depths. The shale units (dark shaded horizons) are modeled with a permeability of $1 \times 10^{-17} \mathrm{~m}^{2}$, and the remaining sediments retain the critical permeability of $2.5 \times 10^{-15} \mathrm{~m}^{2}$ except for the last model that was run with a slightly higher permeability of $5 \times 10^{-15} \mathrm{~m}^{2}$. Dark gray arrows denote general flow directions, while small black arrows are simulated mass $(a, c, e)$ or heat $(b, d, f)$ flux vectors (scaled by magnitude).

[34]. In this model, the depth-dependent permeability relationship, $\zeta(\mathrm{z})$, is given by

$$
\begin{aligned}
& \zeta(z)=\left[e^{-(z / 250)}\right], \quad z \leq 800 \mathrm{~m} \text { below sea floor, } \\
& \zeta(z)=\zeta(800 \mathrm{~m})\left(\frac{z}{800 \mathrm{~m}}\right)^{-3.2}, \quad z>800 \mathrm{~m} \text { below sea floor. }
\end{aligned}
$$

Permeability values at the sea floor $\left(k_{s}\right)$ are assigned using estimates for Gulf Coast sediments from Harrison and Summa [22]. The sea floor sediments are assigned a permeability $\left(k_{s}\right)$ of $1 \times 10^{-12} \mathrm{~m}^{2}$, resulting in a minimum permeability of $1 \times 10^{-16} \mathrm{~m}^{2}$. Sediments and salt retain all other thermal and physical properties shown in Tables 1 and 2 .

The presence of depth-decaying permeability reorganizes the thermal structure of the minibasin (Figure 8). The low permeability surface sediments allow cold seawater to infiltrate deep into the minibasin, depressing temperatures throughout the basin. Instead of convective plumes, narrow zones of upwelling warm waters develop. In this geometric configuration, fluid flux up the flank of the diapir increases, causing the zone of warm waters near the diapir to narrow. Isotherms are deflected, becoming subparallel to the saltsediment interface. In addition, there is a distinct boundary between upward and downward heat transfer within the minibasin (Figure 8). This boundary is particularly sensitive to the magnitude of the basal heat flux: when the basal heat 


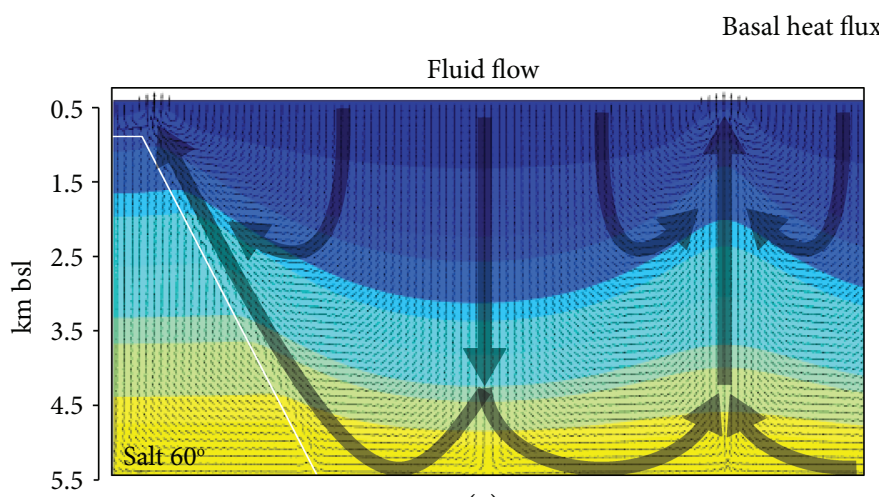

(a)

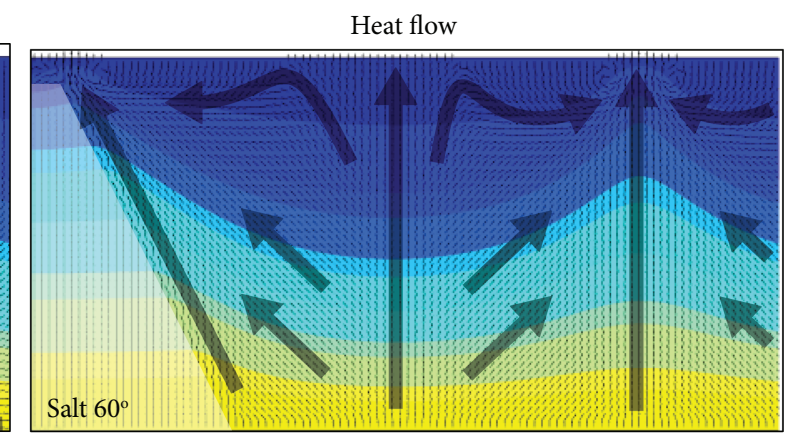

(b)

Basal heat flux $63 \mathrm{~mW} \mathrm{~m}^{-2}$

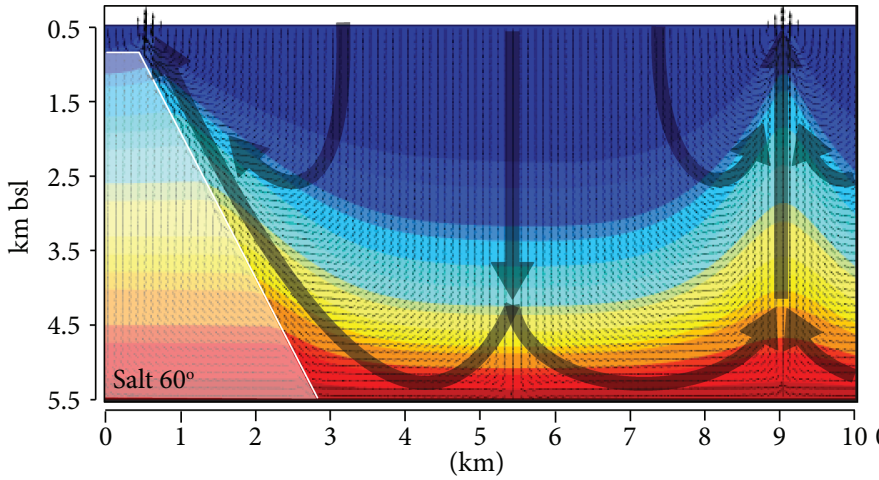

(c)

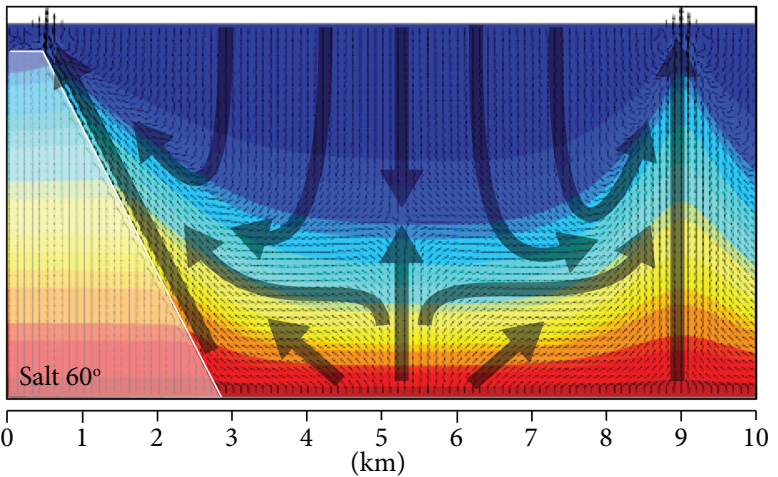

(d)

Fluid flow vectors $\left(\mathrm{kg} \mathrm{s}^{-1} \mathrm{~m}^{-2}\right)$

Max: $4.8 E-5$

Min: $2 E-12$

Heat flow vectors $\left(\mathrm{W} \mathrm{m}^{-2}\right)$

Max: 7.11

Min: $1.5 E-5$

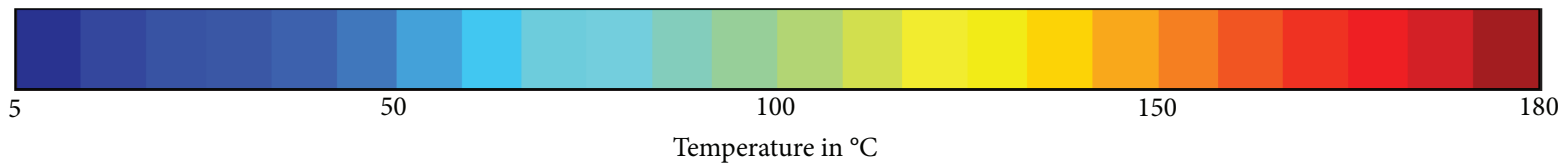

FIGURE 8: Effects of depth-dependent permeability on fluid flow $(a, c)$ and heat flow $(b, d)$ near an axially symmetric diapir with a $60^{\circ}$ dipping salt-sediment interface. The top model was run with a basal heat flux of $40 \mathrm{~mW} \mathrm{~m}^{-2}$, and the bottom model was run with a basal heat flux of $63 \mathrm{~mW} \mathrm{~m}^{-2}$. Dark gray arrows denote general flow directions, while small black arrows are simulated mass (a, c) or heat (b, d) flux vectors (scaled by magnitude).

flux increases, the boundary between upward and downward heat flow is depressed to greater depths. This effect is related to increasing fluid velocities, causing increased discharge at the diapir crest that is balanced by an influx of cold seawaters further into the minibasin. Since the fluids are discharging with a high velocity at a discrete point, the area of infiltrating cold waters is broad, but infiltration rates are relatively slow, resulting in a wider area of colder temperatures.

\subsection{Depth-Dependent Permeability and Stratigraphic} Architecture. We tested a combination of stratigraphic heterogeneity and depth-dependent permeability to examine the behavior of a more realistic, complex hydrologic regime (Figure 9). Sealing units were modeled as shales with permeability an order of magnitude lower than the surrounding sediments. The geothermal gradient was set at $35^{\circ} \mathrm{C} \mathrm{km}^{-1}$ ( $63 \mathrm{~mW} \mathrm{~m}^{-2}$ basal heat flux), and the sediments retain the idealized properties of sandstone, salt, or shale (Table 1).
The addition of stratigraphic heterogeneity reduces the infiltration of cold seawaters and increases temperatures throughout the basin; the sealing layers cause distinct fluid systems to develop within each permeable horizon (Figure 9). Fluid circulation occurs in each of these horizons, but the thermal structure of each horizon is considerably different. Conduction dominates in the basal reservoir where permeability is low, and thus, fluid velocities are low. Advection begins to affect this system very near the salt-sediment interface, although the effect on the thermal structure is minor. In the middle units with moderate permeability, we see a transitional system where advective heat transfer starts to alter the thermal structure near the salt-sediment interface. Heat is advected up the diapir flank, but again, the reorganization of the thermal structure is relatively minor. In the upper two permeable horizons, advection transfers heat up the diapir flank and away from the diapir in the upper portions of the permeable intervals. The thermal anomaly 


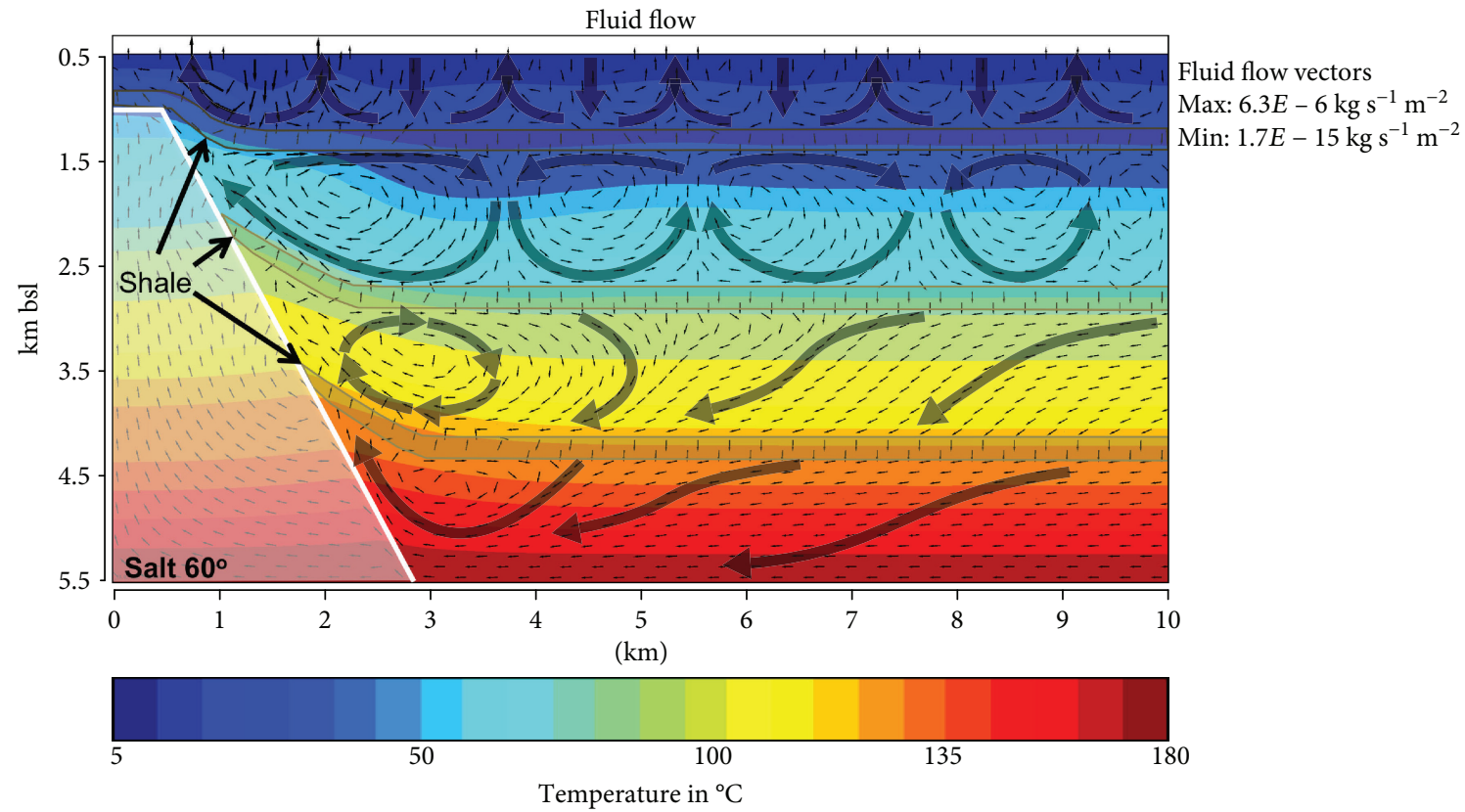

(a)

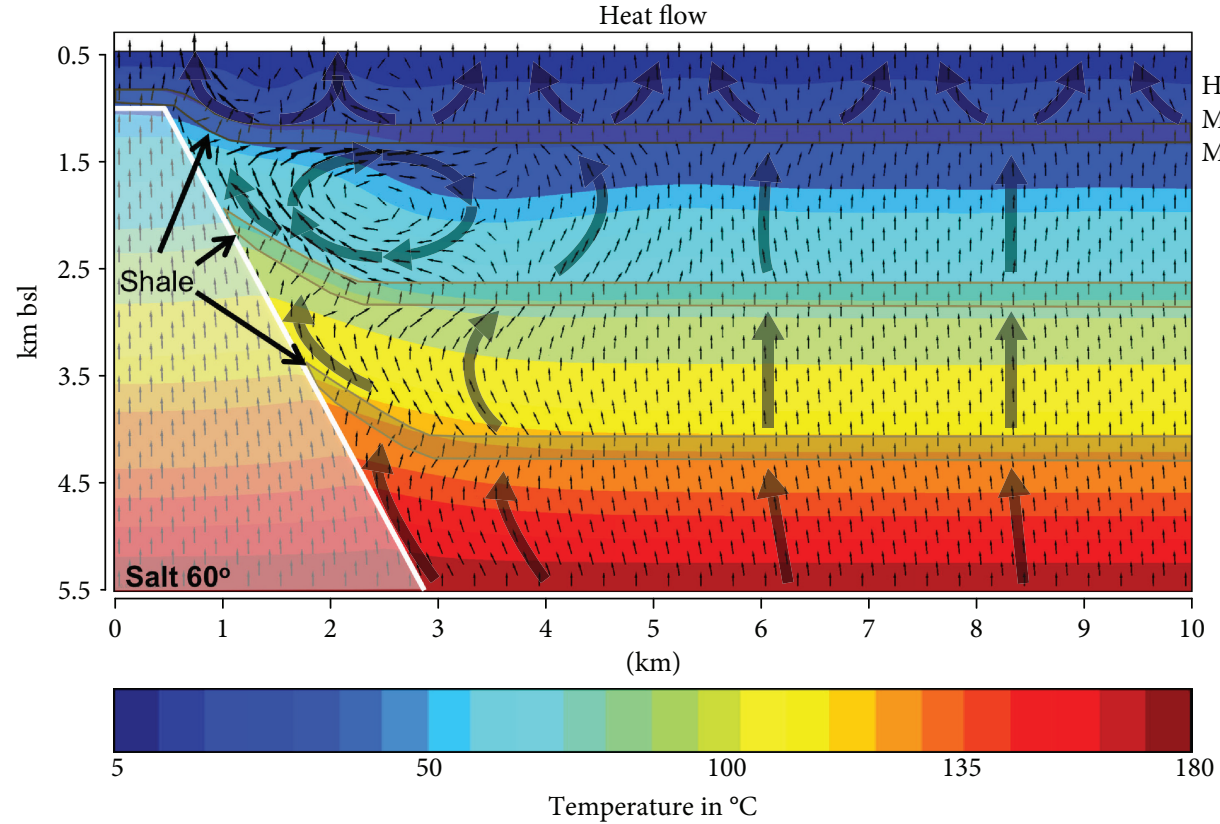

(b)

Figure 9: Fluid (a) and heat flow (b) patterns in a model with three sealing layers, depth-dependent permeability, and a $60^{\circ}$ dipping saltsediment interface. The model was run with a basal heat flux of $63 \mathrm{~mW} \mathrm{~m}^{-2}$. Advection dominates in the two upper reservoirs and conduction dominates in the basal reservoir, with advection beginning to affect the sediments adjacent to the salt in the middle reservoir. Dark gray arrows denote general flow directions, while small black arrows are simulated mass (a) or heat (b) flux vectors (scaled by magnitude).

associated with the salt chimney effect is largely controlled by the discharge of warm fluids at the diapir margin (Figure 9). Fluid velocities increase adjacent to the diapir, and cold waters are advected deeper into the system. In the upper unit, which is in direct communication with the ocean, advection of heat is the dominant heat transport mechanism, with thermal convection cells developing adjacent to the crest of the diapir (Figure 9).
3.5. Depth-Dependent Permeability and Thermohaline Effects. In order to understand how salt dissolution from the diapir affects fluid circulation patterns, the model domains presented and discussed in Section 3.3 (Figure 8) are utilized for transient reactive transport simulation to account for salt dissolution and transport. In these reactive transport simulations, the diapir is modeled as a homogenous body of solidphase $\mathrm{NaCl}$ with hydraulic properties presented in Table 1. 


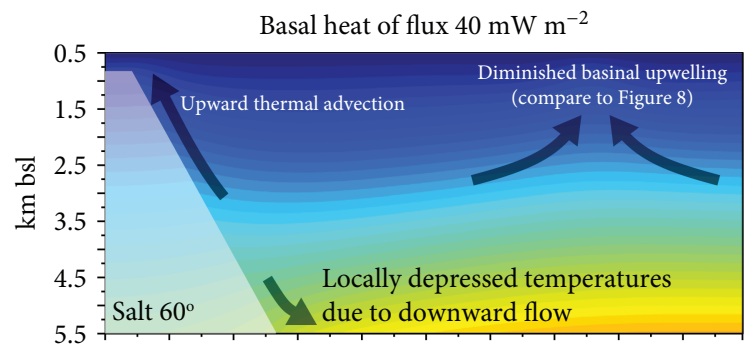

(a)

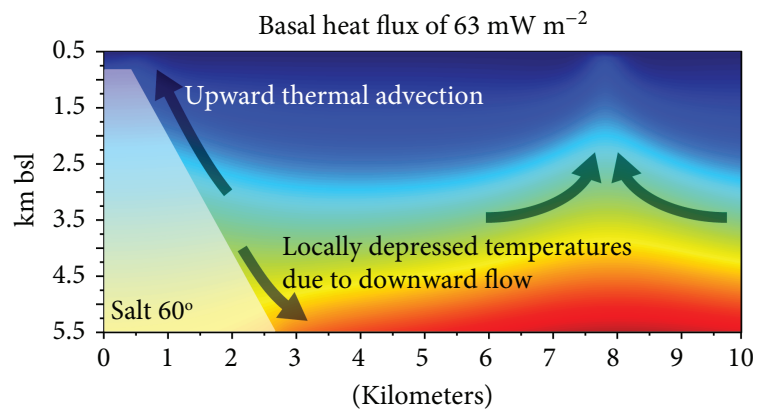

(c)

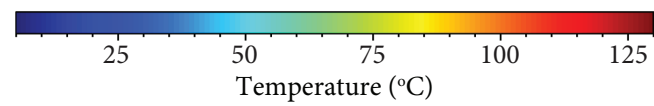

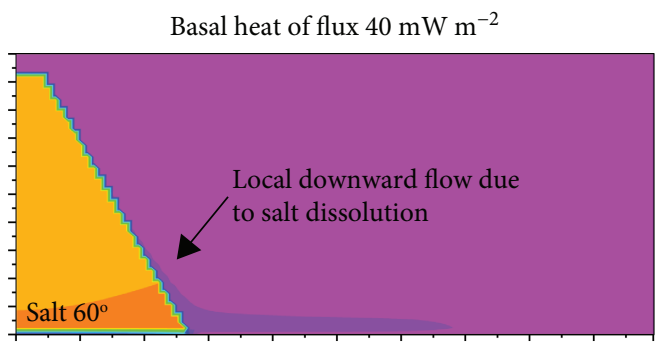

(b)

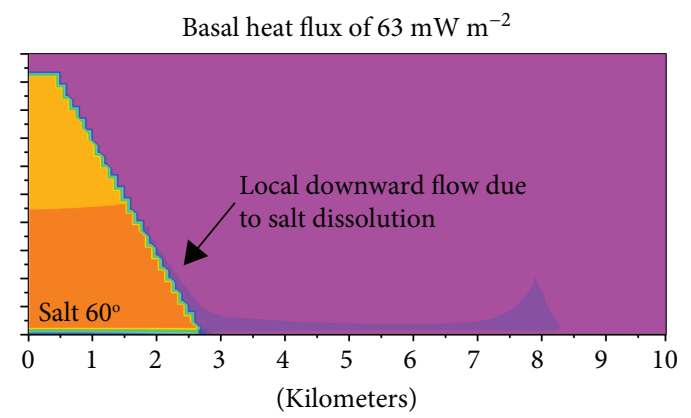

(d)

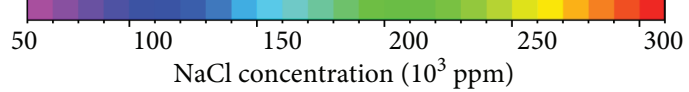

FIGURE 10: Effects of depth-dependent permeability and salt dissolution and transport on the thermal structure and brine concentration near an axially symmetric diapir with a $60^{\circ}$ dipping salt-sediment interface. Panels (a) and (b) show the model result with basal heat flux of $40 \mathrm{~mW} \mathrm{~m}^{-2}$, and panels (c) and (d) show the model results with a basal heat flux of $63 \mathrm{~mW} \mathrm{~m}^{-2}$. These simulations comprise the same geometry and hydraulic parameters as Figure 8 and provide a basis for assessing the relative contributions of thermal and salt transport to thermal structure when permeability decays with depth. Dark gray arrows denote general flow directions.

Minibasin fluids are initially specified with a brine concentration of 58,000 ppm, which is congruent with salt concentrations in the vicinity of the Napoleonville Dome [37]. Salt dissolution is simulated on the basis of local equilibrium, transport is purely advective (chemical diffusion is not simulated), and hydraulic and thermal properties are static throughout the simulation (no permeability or porosity alteration by dissolution, and the thermal conductivity of salt is not temperature-dependent). We used a transient model with 500,000 years of simulation time to maintain consistency and facilitate comparison with the pure water models discussed previously.

Results from these simulations indicate that the overall thermal fluid structure presented in Section 3.3 is largely unaffected by the occurrence of salt dissolution from the diapir; however, the effects of salt dissolution do cause a region of downward, density driven flow along the salt-sediment interface between 3.5 and $5.5 \mathrm{~km}$ depth (Figure 10). Where present, this downward flow locally decreases temperatures along the salt-sediment interface, but the effects are insufficient to inhibit the elevated fluid temperatures along the salt-sediment interface at shallow depths. Comparing the $40 \mathrm{~mW} \mathrm{~m}^{-2}$ and $63 \mathrm{~mW} \mathrm{~m}^{-2}$ models indicates that far-field thermal upwelling in the minibasin is minimally affected by salt dissolution. Minibasin upwelling is suppressed in the lower heat flux model, whereas the thermal signature of the higher heat flux model is nearly identical to models without salt dissolution (compare the lower right image of Figure 8 with the lower left image of Figure 10). The principal difference between the higher heat flux models is a dramatic reduction in temperatures in a narrow (i.e., <100 m) zone along the salt-sediment interface of the model including salt dissolution (Figure 10). These results suggest that salt dissolution primarily affects fluid circulation and temperature near the salt-sediment interface at depths below $3.5 \mathrm{~km}$, whereas far-field thermal fluid circulation is more sensitive to basal heat flux than salinity gradients. Similarly, these simulations represent the only model scenario where we see downward fluid movement along the salt-sediment interface although the salt chimney effect is still largely controlled by advective heat transfer.

\section{Discussion}

"Remember, all models are wrong; the practical question is how wrong do they have to be to not be useful... essentially, all models are wrong but some are useful" [38]. Even though the models presented here are highly simplified and cannot hope to capture all aspects of real-world scenarios, they do provide important insights into the fundamental controls on the behavior and evolution of the thermal structure near salt diapirs and in their adjacent minibasins. Predictions based on these models can help to refine our understanding and interpretation of petroleum systems near salt structures 
with steep to moderately dipping boundaries and provide guidelines for interpreting the long-term thermal history and fluid system evolution around more complex salt structures. The models also provide a baseline against which similar models incorporating more complicated geochemical and geomechanical processes may be compared, thereby determining their relative impacts on fluid circulation near salt.

\subsection{Coevolution of Diapirs and Their Associated Fluid} Systems. Fluid systems near salt should be influenced by the structural evolution of the diapir and thus the halokinetic evolution of the adjacent minibasin strata. Passive diapirs generally grow via a downbuilding process where dense sediments "sink" into the surrounding, less dense salt $[39,40]$. Therefore, as diapirism commences, the salt-sediment interface will develop from subhorizontal to vertical and sometimes even to overhanging $[39,40]$.

Despite the fact that we do not explicitly model an evolving salt diapir geometry, our numerical modeling of different diapir margin dips can be used as a proxy for diapir evolution. These models suggest that advective heat transport dominates in the early stages of diapirism when the saltsediment interface dips at low angles and sediments are relatively uncompacted, retaining high porosity and permeability. As diapirism and sedimentation continue, the dip of the salt-sediment interface will evolve into a more vertical orientation, and compaction of sediments in the minibasin will result in decreased porosity and permeability with depth $[22,34-36]$. Our models suggest that in these stages of diapir evolution, advective heat transport will progressively diminish and conduction through the sediments will begin to control the thermal structure of the minibasin (Figure 11). Advected warm waters could degrade hydrocarbons along the salt-sediment interface early in salt diapirism while preserving organic material deeper in the minibasin where the slow infiltration of seawater causes decreased temperatures. As sedimentation continues and stratigraphic heterogeneity increases, sediments at depth will see a reduction in porosity and permeability, and thus, fluid velocities will diminish. When shales or other low permeability rocks are deposited on top of a permeable horizon, they will trap the circulating fluids, thus creating a distinct fluid system below and above the seal, effectively isolating the reservoir.

In the later stages of diapirism when the salt structure is vertical to overhanging and sediments define a complex and heterogeneous permeability structure, conduction through the diapir will control the thermal structure, only slightly altering temperatures in the minibasin, with the thermal anomaly associated with the salt chimney effect controlled by conduction through the salt. Figure 11 shows a hypothetical schematic evolution of a passive diapir and the accompanying evolution of fluid system structure through early, middle, and late stages of passive diapirism. Kühn and Günther [41] showed that free thermal convection is primarily dependent on the geometry of the reservoir, similar to the conclusions of this work, where thermal convection is strongly dependent on the geometry of the salt diapir. Furthermore, the direction of fluid flow will greatly influence whether faults and fractures transmit fluid up the stratigraphic column or down through the stratigraphic column [42]. It is evident that faults and fractures within about $1 \mathrm{~km}$ of the salt diapir (and especially within sealing layers) will readily facilitate upward fluid migration, whereas faults and fractures in the center of the minibasin will likely transmit cool waters deeper into the minibasin.

\subsection{Depth-Decaying Permeability and Stratigraphic} Heterogeneity: Implications for Real-World Fluid Systems near Salt. A constant permeability change with depth is probably the most important and most commonly overlooked aspect to the fluid system and thermal structure of minibasins. Many studies have shown that there is consistent permeability/porosity decay with depth in sedimentary basins around the world [22, 43]. The addition of simple depth-dependent permeability in our models causes the structure of convective plumes to narrow into discrete zones of upwelling (Figure 8). Many recent studies show the development of complex convection cells in thick and permeable reservoirs near salt structures (e.g., $[37,44]$ ). It is likely that one or two convection cells may develop adjacent to a salt diapir, but our models suggest that a chain of convection cells extending many kilometers into the adjacent minibasin in a permeable horizon is unlikely, particularly because our thermohaline simulations suggest that such convection is likely to be controlled by interactions between regional heat flux and natural brine concentration. In addition, the structure of these convection cells likely reflects the geometries observed in the present models. Instead of a distinct, welldeveloped convective plume, warm waters are more likely to ascend via narrow zones of upwelling.

In the Kwanza basin, offshore Angola, the fluid system and thermal structure are tightly coupled with thermal advection of warm seawaters increasing temperatures above and adjacent to salt diapirs and resulting in the formation of fluid escape features at the seafloor near the crest of diapirs and along the edges of salt sheets [44]. Serié et al. [44] identify features including pockmarks, mud and asphalt volcanoes, and surface slicks as well as shallow subsurface paleopockmarks, indicating a strong correlation between the petroleum system, fluid system, and thermal structure within the minibasins. Similar features are seen in the Gulf of Mexico and are shown on the 2017 US Bureau of Ocean Energy Management's Gulf of Mexico Deepwater Bathymetry Grid. Serié et al. [44] further noted elevated temperatures above salt domes (i.e., the salt chimney effect), which they attributed to fluid advection along high permeability, inclined strata adjacent to salt structures. Although intuition might suggest that elevated temperatures above and adjacent to salt would be associated with elevated geothermal gradients in the surrounding minibasin, the present models indicate that high fluid discharge near the diapir crest is likely associated with slow infiltration of cold waters that will depress geotherms in the middle of the minibasin. Consequently, the depressed temperatures could preserve hydrocarbons that would otherwise be overmature at their current position. Anomalous pockmarks in the center of minibasins could be associated with the advected warm waters ascending via narrow 


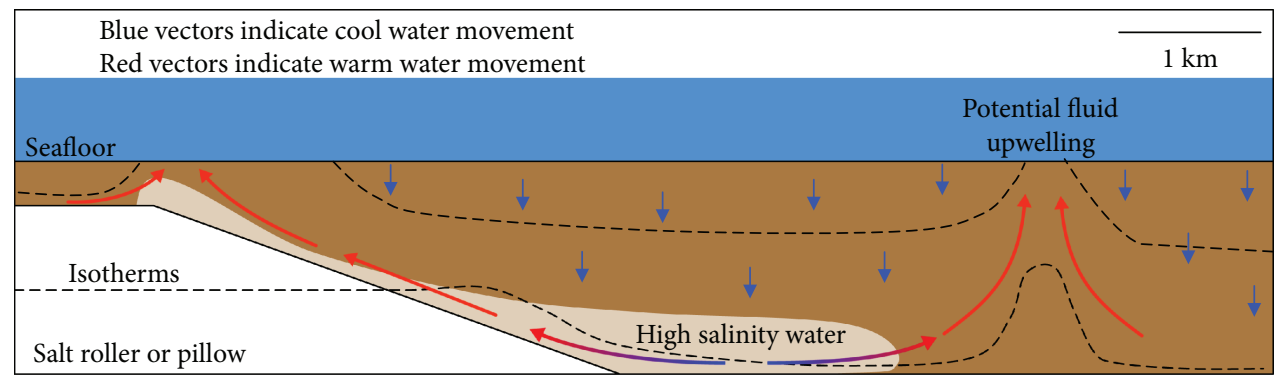

(a)

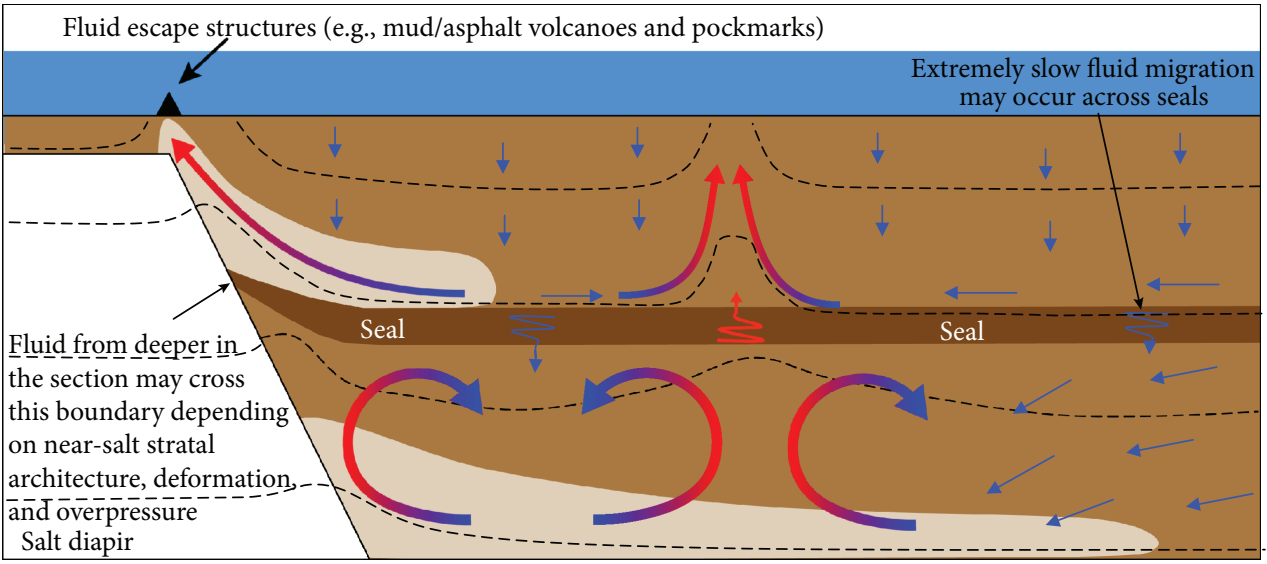

(b)

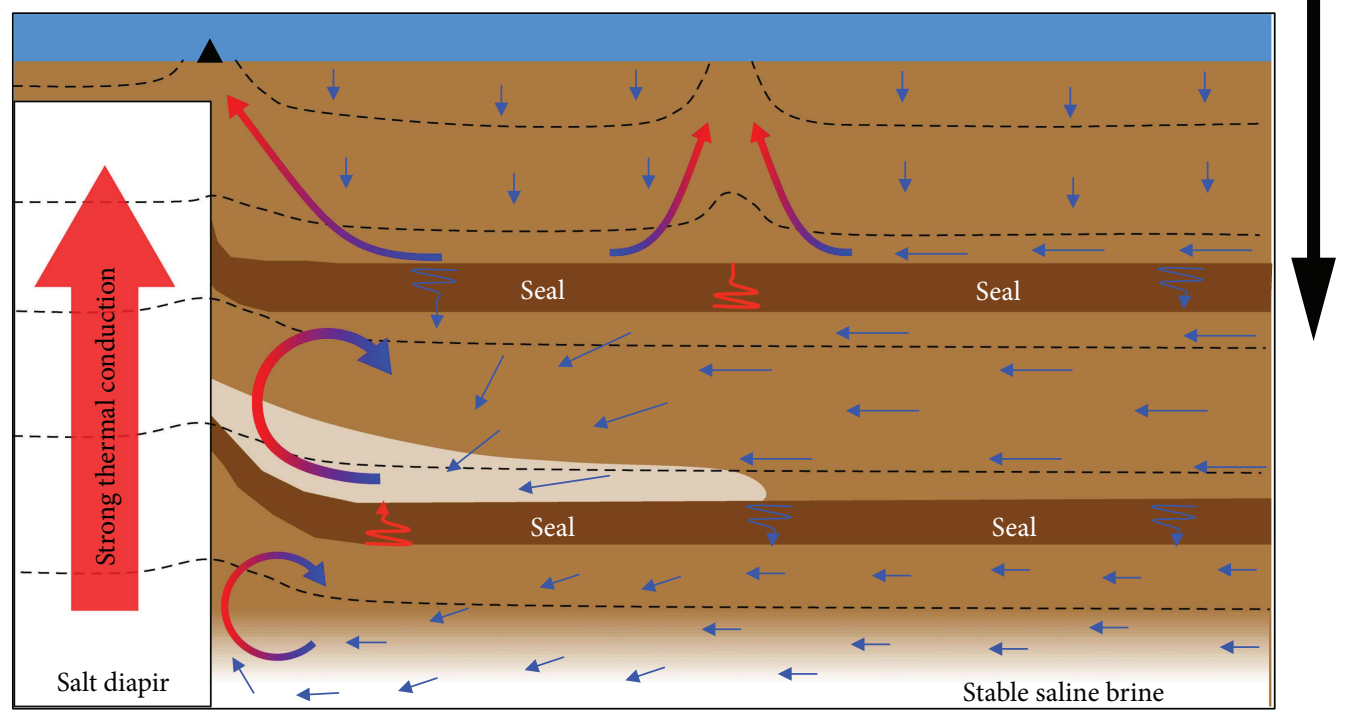

(c)

FIGURE 11: Schematic illustration of the evolution of the thermal and fluid system structure near a passively growing salt diapir. Note that the near-salt stratal architecture is highly simplified and should not be taken to represent specific truncation, pinchout, or folded geometries of seal or reservoir rocks. The diagram also omits any near-salt deformation or mineralization, both of which could locally alter porosity and permeability and, thus, fluid system structure. (a) Early in diapirism, advective heat transport controls the thermal structure of the basin with distinct zones of upwelling warm waters adjacent to the diapir and deeper in the minibasin. (b) During an intermediate stage of diapir evolution, the thermal structure is a result of both advective heat transport and thermal conduction through the salt, producing a combined thermal structure with advective heat transport dominating in the upper reservoir and beginning to wane in the lower reservoir. (c) A mature salt diapir with complex, heterogeneous stratigraphy. The impact of advective heat transport is diminished and only affects sediments adjacent to the salt-sediment interface. Conduction controls the thermal structure in the basal units with advection, and likely thermohaline convection, taking place in the high permeability shallow units. Dense saline brines have stabilized in the deepest reservoir rocks. 
zones similar to the geometries observed in the present models (e.g., Figure 8).

Pipes, faults, fractures, and other secondary porosity features near the diapir margin (within $\sim 1 \mathrm{~km}$ ) will likely transmit fluids upward, whereas structures deeper in the minibasin may allow more efficient infiltration of cold waters (Figure 11; [44, 45]). Seal bypass systems (faults and fractures) will likely enhance advective heat transfer because these pathways represent highly permeable zones that will readily transmit fluids vertically through the stratigraphic section. The location of faults and fractures could therefore have a significant effect on thermal maturation, preserving hydrocarbons where cold waters percolate down along faults and degrading hydrocarbons where warm waters are ascending near the salt-sediment interface. Furthermore, the direction of fluid flow has direct impacts on the location of hydrocarbon traps with high fluid velocities away from the diapir working to counteract buoyancy forces associated with petroleum migration, leaving promising traps void of hydrocarbon accumulations. Similarly, our reactive transport models suggest that significant salt dissolution could cause fluid flow down the flank of the diapir which could also flush hydrocarbons from promising traps.

In the Gulf of Mexico, many field studies clearly show three distinct hydrogeologic zones (e.g., [4, 18, 22, 32, 46-48]). The hydrogeologic zones are characterized by (1) seawater salinities and normally pressured waters in the lowest hydrologic zone, (2) overpressured, high salinity waters found in the middle zone, and (3) normally pressured seawater in communication with open ocean waters in the upper zone. As shown in the thermohaline simulations presented here, it is also possible for density gradients associated with salt dissolution to overwhelm the density gradients associated with thermal convection (Figure 10). However, over time, as high salinity brines stabilize, thermal convection will again drive fluid flow $[8,28,49]$. The presence of haline and thermohaline driven convection cells is likely a transient process associated with fault valve behavior and release of overpressured, higher salinity fluids [49]. Over geologic time, thermal convection is likely the main driver of fluid flow near salt diapirs, particularly as salt concentrations stabilize in the minibasin and/or approach equilibrium with the adjacent diapir.

The upper zone of the three part fluid system is dominated by free thermal convection often associated with salt dissolution at the diapir crest [8]. Wilson and Ruppel [8] showed that thermohaline convection dominates only when salt dissolution is active, and over time, when salinity gradients stabilize, thermal convection again becomes the dominant groundwater driver. This, accompanied by the high permeability sediments in the shallow groundwater zone shows that free thermal convection is most likely the dominant groundwater driver over long periods of time and that advection is the main heat transport process in shallow sediments both in deepwater and shallow water settings, increasing temperatures adjacent to diapirs and decreasing temperatures in the basin (e.g., [44]).

Overpressured fluids that range in salinity characterize the middle hydrogeologic zone [32, 50-54]. Overpressures are a rate-dependent phenomenon and depend upon the rate and amount of fluid volume change, fluid flow (into and out of the system), and the rate of pore space creation or reduction (i.e., compaction, fracturing, cementation, etc., [50, 52-55]). Fluid pressures throughout all of our model runs remain hydrostatic, suggesting that thermal expansion of water alone is likely not responsible for overpressures observed in basins like the Gulf of Mexico. Overpressures are closely related to undercompacted horizons, which are characterized by increased porosity and, in turn, have been interpreted to induce low thermal conductivities (i.e., act as a thermal barrier, e.g., $[53,55])$. When considering conductive heat transport, this is an adequate interpretation, although when bearing in mind advective heat transport, we come to the opposite conclusion. Increases in porosity are roughly correlative with increases in permeability and thus would accommodate higher fluid velocities, which in turn would favor advective heat transport and could drastically alter the thermal structure of undercompacted horizons.

Fluid advection during the initial stages of diapirism could help explain why we see high salinity brines in deep reservoirs in the Gulf of Mexico [32]. Early in the history of diapirism, the shallow dip of salt structures and the relatively high permeability of shallow sediments will favor advective heat transport and increased fluid velocities. High fluid velocities would stimulate salt dissolution, creating high salinity brines that would later become trapped in the basal reservoir as diapirism continues and sealing layers are deposited. As sediments become progressively buried through downbuilding, porosity and permeability will decrease and fluid velocity will decline, resulting in decreased dissolution over time and eventually the stagnation and accumulation of high salinity brines in deep reservoirs.

\section{Conclusion}

Salt diapirs exert a significant control on the thermal structure of many sedimentary basins creating large regions with abnormal temperature distributions and intricate fluid systems. These temperature distributions are controlled by thermal conduction through the salt and enveloping sediments and by advecting warm waters near the salt and in the adjacent minibasins. The main controls on the thermal structure of the minibasin are (1) the permeability structure of the sediments, (2) the geometry of the salt structure, and (3) the structural evolution of the diapir and basin. In this paper, we used numerical models to investigate the first two of these controls. Simple permeability structure is examined by incorporating a systematic change in permeability with depth and by adding low permeability horizons at different depths in the minibasin. Salt structural geometry is modeled by changing the homoclinal dip of a diapir margin. Decreasing the dip of a salt-sediment interface induces advective heat transfer, and the resulting fluid circulation causes flow up the diapir flank. As dips increase, advection decreases and the thermal structure is dominated by conduction. The presence of laterally continuous sealing layers in the minibasin also decreases the overall effects of advective heat transfer. In 
the presence of these layers, the fluid system becomes stratigraphically compartmentalized, and the salt chimney effect is dominated by conduction. Systematic, depth-dependent permeability results in heat being advected up the diapir in a narrower zone, with increased flow at the diapir margin, and we show how this phenomenon is affected by thermal input and salt dissolution from the adjacent diapir. Cold waters are advected deeper into the basin, and the salt chimney effect is dominated by advection. In a model that combines all of these characteristics, conductive heat transfer dominates in the basal units with advection affecting the middle layers of the model and dominating in the upper units. Advection likely dominates in shallow sediments with relatively high permeability.

This study also suggests important changes in fluid system structure during evolution of a diapir. As diapirs grow, they generally start as salt pillows or anticlines with shallow dipping flanks and then evolve vertically into more complex stocks, walls, and sheets that are all formed by increasing dips along the salt-sediment interface. When accompanied by the permeability reduction as sediments are buried, this suggests that advection likely dominates in the early stages of diapirism when salt structures have shallow dips and sediments reside at relatively shallow depths. As the salt structures mature into more complex geometries, advection will diminish due to the increase in dip of the salt-sediment interface and the increased hydraulic heterogeneity due to complex sedimentation. Despite the simplicity of these models, the results of this work provide guidelines for interpreting the long-term thermal history and fluid system evolution around more complex salt structures, offering a theoretical model to compliment other techniques of investigation to improve our appraisals of source rock maturation, as well as hydrocarbon migration and distribution in these structurally and stratigraphically complex settings.

\section{Data Availability}

The data used to support the findings of this study are available from the corresponding author upon request.

\section{Disclosure}

An earlier version of the manuscript was presented as an abstract in the GSA Annual Meeting in Denver, Colorado, USA, 2016.

\section{Conflicts of Interest}

The authors declare that they have no conflicts of interest.

\section{Acknowledgments}

Major financial support was generously provided by past and present sponsors of the Salt-Sediment Interaction Research Consortium (S-SIRC) at the University of Texas at El Paso. The American Association of Petroleum Geologists Grantsin-Aid and the Geological Society of America/ExxonMobil
Student Research Grants also contributed to the financial support of this project. The authors would also like to thank Mark Rowan, Katherine Giles, and Nicholas Williams for thought provoking discussions regarding fluid system evolution near salt structures.

\section{References}

[1] T. Banga, R. M. Capuano, and D. S. van Nieuwenhuise, "Fluid flow, stratigraphy and structure in the vicinity of the South Liberty salt dome, Texas," Gulf Coast Association of Geological Societies Transactions, vol. 52, pp. 25-36, 2002.

[2] M. Cacace and M. Scheck-Wenderoth, "Modeling the thermal field and the impact of salt structures in the north east German basin," in Proceedings World Geothermal Congress 2010, pp. 1540-1540, Bali, Indonesia, 2010.

[3] N. M. Downs, The Effects of Salt Diapirs on the Thermal Maturity of Surrounding Sediments in the Western Pyrenees, Spain, [Ph.D. thesis], University of Nevada, Las Vegas, 2012.

[4] W. L. Esch and J. S. Hanor, "Fault and fracture control of fluid flow and diagenesis around the Iberia Salt Dome, Iberia Parish, Louisiana,” AAPG Bulletin, vol. 79, pp. 1558-1558, 1995.

[5] J. Forrest, E. Marcucci, and P. Scott, "Geothermal gradients and subsurface temperatures in the northern Gulf of Mexico," Gulf Coast Association of Geological Societies Transactions, vol. 55, pp. 233-248, 2005.

[6] B. O. Kaiser, M. Cacace, M. Scheck-Wenderoth, and B. Lewerenz, "Characterization of main heat transport processes in the Northeast German Basin: constraints from 3-D numerical models," Geochemistry, Geophysics, Geosystems, vol. 12, no. 7, 2011.

[7] F. Magri, U. Bayer, A. Pekdeger, R. Otto, C. Thomsen, and U. Maiwald, "Salty groundwater flow in the shallow and deep aquifer systems of the Schleswig-Holstein area (North German Basin)," Tectonophysics, vol. 470, no. 1-2, pp. 183-194, 2009.

[8] A. Wilson and C. Ruppel, "Salt tectonics and shallow subseafloor fluid convection: models of coupled fluid-heat-salt transport," Geofluids, vol. 7, no. 4, pp. 377-386, 2007.

[9] D. G. Evans, J. A. Nunn, and J. S. Hanor, "Mechanisms driving groundwater flow near salt domes," Geophysical Research Letters, vol. 18, no. 5, pp. 927-930, 1991.

[10] B. O. Kaiser, M. Cacace, and M. Scheck-Wenderoth, "3D coupled fluid and heat transport simulations of the Northeast German Basin and their sensitivity to the spatial discretization: different sensitivities for different mechanisms of heat transport," Environmental Earth Sciences, vol. 70, no. 8, pp. 3643-3659, 2013.

[11] F. Magri, U. Bayer, U. Maiwald, R. Otto, and C. Thomsen, "Impact of transition zones, variable fluid viscosity and anthropogenic activities on coupled fluid-transport processes in a shallow salt-dome environment," Geofluids, vol. 9, no. 3, pp. 182-194, 2009.

[12] M. Scheck-Wenderoth, M. Cacace, Y. P. Maystrenko et al., "Models of heat transport in the Central European Basin System: effective mechanisms at different scales," Marine and Petroleum Geology, vol. 55, pp. 315-331, 2014.

[13] Z. Yu, I. Lerche, and A. Lowrie, "Thermal impact of salt: Simulation of thermal anomalies in the gulf of Mexico," Pure and Applied Geophysics, vol. 138, no. 2, pp. 181-192, 1992. 
[14] Q. G. Zhuo, F. W. Meng, M. J. Zhao, Y. Li, X. S. Lu, and P. Ni, "The salt chimney effect: delay of thermal evolution of deep hydrocarbon source rocks due to high thermal conductivity of evaporites," Geofluids, vol. 16, no. 3, pp. 440451, 2016.

[15] H. H. Posey and J. R. Kyle, "Fluid-rock interactions in the salt dome environment: an introduction and review," Chemical Geology, vol. 74, no. 1-2, pp. 1-24, 1988.

[16] F. Magri, R. Littke, S. Rodon, U. Bayer, and J. L. Urai, "Temperature fields, petroleum maturation and fluid flow in the vicinity of salt domes," in Dynamics of Complex Intracontinental Basins: The Central European Basin System, pp. 323-344, Springer, Berlin, Germany, 2008.

[17] J. J. O'Brien and I. Lerche, "Modelling of the deformation and faulting of formations overlying an uprising salt dome," in Dynamical Geology of Salt and Related Structures, I. Lerche and J. J. O'Brien, Eds., pp. 419-455, Academic Press, London, $\mathrm{UK}, 1987$.

[18] A. Sarkar, J. A. Nunn, and J. S. Hanor, "Free thermohaline convection beneath allochthonous salt sheets: an agent for salt tectonics and fluid flow in Gulf Coast sediments," in Gulf Coast Section, Society of Economic Paleontologists and Mineralogists Foundation Annual Research Conference, vol. 16, pp. 245-252, Houston, TX, USA, 1995.

[19] M. B. Dusseault, V. Maury, F. Sanfilippo, and F. J. Santarelli, "Drilling around salt: risks, stresses, and uncertainties," in Gulf Rocks 2004, the 6th North America Rock Mechanics Symposium (NARMS), p. 19, Houston, TX, USA, 2004, American Rock Mechanics Association.

[20] E. C. Robertson, Thermal Properties of Rocks, U.S. Geological Survey, Reston, VA, USA, 1988.

[21] I. Lerche, "Temperature dependence of thermal conductivity and its impact on assessments of heat flux," Pure and Applied Geophysics, vol. 136, no. 2-3, pp. 191-200, 1991.

[22] W. J. Harrison and L. L. Summa, "Paleohydrology of the Gulf of Mexico basin," American Journal of Science, vol. 291, no. 2, pp. 109-176, 1991.

[23] K. Pruess, C. M. Oldenburg, and G. J. Moridis, TOUGH2 User's Guide Version 2 (No. LBNL-43134), Ernest Orlando Lawrence Berkeley National Laboratory, Berkeley, CA, USA, 1999.

[24] IFC, A Formulation of the Thermodynamic Properties of Ordinary Water Substance, International Formulation Committee (IFC) Secretariat, Dusseldorf, Germany, 1967.

[25] Y. Jung, G. S. H. Pau, S. Finsterle, and R. M. Pollyea, "TOUGH3: A new efficient version of the TOUGH suite of multiphase flow and transport simulators," Computers \& Geosciences, vol. 108, pp. 2-7, 2017.

[26] L. Pan, N. Spycher, C. Doughty, and K. Pruess, "ECO2N V2.0: a TOUGH2 fluid property module for modeling $\mathrm{CO}_{2}-\mathrm{H}_{2} \mathrm{O}-$ NACL systems to elevated temperatures of up to $300^{\circ} \mathrm{C}$," Greenhouse Gases: Science and Technology, vol. 7, no. 2, pp. 313-327, 2017.

[27] S. Geiger, T. Driesner, C. A. Heinrich, and S. K. Matthäi, "On the dynamics of $\mathrm{NaCl}-\mathrm{H}_{2} \mathrm{O}$ fluid convection in the Earth's crust," Journal of Geophysical Research, vol. 110, no. B7, 2005.

[28] J. M. Sharp Jr., T. R. Fenstemaker, C. T. Simmons, T. E. McKenna, and J. K. Dickinson, "Potential salinity-driven free convection in a shale-rich sedimentary basin: example from the Gulf of Mexico Basin in South Texas," AAPG Bulletin, vol. 85, pp. 2089-2110, 2001.
[29] C. T. Simmons, T. R. Fenstemaker, and J. M. Sharp Jr., "Variable-density groundwater flow and solute transport in heterogeneous porous media: approaches, resolutions and future challenges," Journal of Contaminant Hydrology, vol. 52, no. 1-4, pp. 245-275, 2001.

[30] M. Huysmans and A. Dassargues, "Review of the use of Péclet numbers to determine the relative importance of advection and diffusion in low permeability environments," Hydrogeology Journal, vol. 13, no. 5-6, pp. 895-904, 2005.

[31] R. L. Van Dam, C. T. Simmons, D. W. Hyndman, and W. W. Wood, "Natural free convection in porous media: first field documentation in groundwater," Geophysical Research Letters, vol. 36, no. 11, 2009.

[32] A. K. Steen, J. A. Nunn, and J. S. Hanor, "Indications of formation water flow and compartmentalization on the flank of a salt structure derived from salinity and seismic data," Geofluids, vol. 11, no. 2, pp. 199-208, 2011.

[33] K. A. Giles and M. G. Rowan, "Concepts in halokineticsequence deformation and stratigraphy," Geological Society, London, Special Publications, vol. 363, no. 1, pp. 7-31, 2012.

[34] C. E. Manning and S. E. Ingebritsen, "Permeability of the continental crust: Implications of geothermal data and metamorphic systems," Reviews of Geophysics, vol. 37, no. 1, pp. 127-150, 1999.

[35] R. M. Pollyea, E. W. van Dusen, and M. P. Fischer, “Topographically driven fluid flow within orogenic wedges: effects of taper angle and depth-dependent permeability," Geosphere, vol. 11, no. 5, pp. 1427-1437, 2015.

[36] M. O. Saar and M. Manga, "Depth dependence of permeability in the Oregon Cascades inferred from hydrogeologic, thermal, seismic, and magmatic modeling constraints," Journal of Geophysical Research: Solid Earth, vol. 109, no. B4, 2004.

[37] Z. Jamshidzadeh, F. T. C. Tsai, H. Ghasemzadeh, S. A. Mirbagheri, M. T. Barzi, and J. S. Hanor, "Dispersive thermohaline convection near salt domes: a case at Napoleonville Dome, southeast Louisiana, USA," Hydrogeology Journal, vol. 23, no. 5, pp. 983-998, 2015.

[38] G. E. P. Box and N. R. Draper, Empirical Model-Building and Response Surfaces, Wiley, New York, NY, USA, 1987.

[39] M. R. Hudec and M. P. A. Jackson, "Terra infirma: understanding salt tectonics," Earth-Science Reviews, vol. 82, no. 1-2, pp. 1-28, 2007.

[40] M. P. A. Jackson, B. C. Vendeville, and D. D. Schultz-Ela, "Structural dynamics of salt systems," Annual Review of Earth and Planetary Sciences, vol. 22, no. 1, pp. 93-117, 1994.

[41] M. Kühn and A. Günther, "Stratabound Rayleigh convection observed in a 4D hydrothermal reactive transport model based on the regional geological evolution of Allermöhe (Germany)," Geofluids, vol. 7, no. 3, pp. 301-312, 2007.

[42] S. J. Roberts and J. A. Nunn, "Episodic fluid expulsion from geopressured sediments," Marine and Petroleum Geology, vol. 12, no. 2, pp. 195-204, 1995.

[43] G. C. Bond and M. A. Kominz, "Construction of tectonic subsidence curves for the early Paleozoic miogeocline, southern Canadian Rocky Mountains: implications for subsidence mechanisms, age of breakup, and crustal thinning," Geological Society of America Bulletin, vol. 95, no. 2, pp. 155-173, 1984.

[44] C. Serié, M. Huuse, N. H. Schødt, J. M. Brooks, and A. Williams, "Subsurface fluid flow in the deep-water Kwanza 
Basin, offshore Angola," Basin Research, vol. 29, no. 2, pp. 149-179, 2017.

[45] J. Cartwright and C. Santamarina, "Seismic characteristics of fluid escape pipes in sedimentary basins: implications for pipe genesis," Marine and Petroleum Geology, vol. 65, pp. 126-140, 2015.

[46] T. Finkbeiner, M. Zoback, P. Flemings, and B. Stump, "Stress, pore pressure, and dynamically constrained hydrocarbon columns in the South Eugene Island 330 field, northern Gulf of Mexico," AAPG Bulletin, vol. 85, pp. 1007-1031, 2001.

[47] B. S. Hart, P. B. Flemings, and A. Deshpande, "Porosity and pressure: role of compaction disequilibrium in the development of geopressures in a Gulf Coast Pleistocene basin," Geology, vol. 23, no. 1, pp. 45-48, 1995.

[48] K. M. McManus and J. S. Hanor, "Diagenetic evidence for massive evaporite dissolution, fluid flow, and mass transfer in the Louisiana Gulf Coast," Geology, vol. 21, no. 8, pp. 727-730, 1993.

[49] C. Ruppel, G. R. Dickens, D. G. Castellini, W. Gilhooly, and D. Lizarralde, "Heat and salt inhibition of gas hydrate formation in the northern Gulf of Mexico," Geophysical Research Letters, vol. 32, no. 4, 2005.

[50] J. R. Alnes, R. A. Lilburn, M. J. Osborne, and R. E. Swarbrick, "Mechanisms for generating overpressure in sedimentary basins: a reevaluation," AAPG Bulletin, vol. 82, pp. 22662271, 1998.

[51] C. Barker, "Aquathermal pressuring: role of temperature in development of abnormal-pressure zones," AAPG Bulletin, vol. 56, pp. 2068-2071, 1972.

[52] J. Hansom and M. K. Lee, "Effects of hydrocarbon generation, basal heat flow and sediment compaction on overpressure development: a numerical study," Petroleum Geoscience, vol. 11, no. 4, pp. 353-360, 2005.

[53] M. J. Osborne and R. E. Swarbrick, "Mechanisms for generating overpressure in sedimentary basins: a reevaluation," $A A P G$ Bulletin, vol. 81, pp. 1023-1041, 1997.

[54] R. E. Swarbrick, M. J. Osborne, and G. S. Yardley, "Comparison of overpressure magnitude resulting from the main generating mechanisms," AAPG Memoir, vol. 76, pp. 1-12, 2002.

[55] U. T. Mello and G. D. Karner, "Development of sediment overpressure and its effect on thermal maturation: application to the Gulf of Mexico basin," AAPG Bulletin, vol. 80, pp. 1367-1396, 1996. 